\title{
Single nucleotide polymorphisms and the risk of developing a second primary cancer among head and neck cancer patients: a systematic literature review and meta- analysis
}

Ilda Hoxhaj ${ }^{1,2}$, Vladimir Vukovic ${ }^{1,3}$, Stefania Boccia ${ }^{1,2^{*}}$ and Roberta Pastorino ${ }^{2}$

\begin{abstract}
Background: Head and Neck Cancer (HNC) survivors are at increased risk of developing a second primary cancer (SPC). Along with the environmental risk factors, genetic factors have been associated with a potential increased susceptibility to SPC development. We aim to identify the Single Nucleotide Polymorphisms (SNPs) that contribute to SPC development among HNC survivors through a systematic review and meta-analysis.

Methods: We searched PubMed, Scopus and ISI Web of Science for eligible studies published in English until January 31st, 2020. We included studies reporting primary data that evaluated the association between SNPs and SPC risk in HNC patients. Data were pooled in a random-effect meta-analyses, when at least two studies on the same SNP evaluated the same genotype model. Heterogeneity was assessed using the X2-based Q-statistics and the $I^{2}$ statistics. Quality of the included studies was assessed using the Q-Genie tool.

Results: Twenty-one studies, of moderate to good quality, were included in the systematic review. Fifty-one genes were reported across the included studies to have significant associations with an increased SPC risk. Overall, 81 out of 122 investigated SNPs were significantly associated with the SPC risk. Seven studies were included in the metaanalysis, which showed five SNPs associated with an increased risk of SPC: $\mathrm{P21C70T,CT}+\Pi \mathrm{T}(\mathrm{HR}=1.76 ; 95 \% \mathrm{Cl}$ : 1.28-2.43); FASLG -844C > T, CT + Tा (HR=1.82; 95\% Cl: 1.35-2.46), P21 C98A, CA + AA (HR=1.75; 95\% Cl: 1.28-2.38); FAS -670A > G (HR=1.84; 95\% Cl: 1.28-2.66) and GST-M1, Null genotype ( $H R=1.54 ; 95 \% \mathrm{Cl}: 1.13-2.10)$.

Conclusions: The identified SNPs in our systematic review and meta-analysis might serve as potential markers for identification of patients at high risk of developing SPC after primary HNC.
\end{abstract}

PROSPERO Registration Number: CRD42019135612.

Keywords: Head and neck cancer, Second primary cancer, Single nucleotide polymorphism, Personalized medicine, Biomarker

\footnotetext{
* Correspondence: stefania.boccia@unicatt.it

'Section of Hygiene, University Department of Life Sciences and Public Health, Università Cattolica del Sacro Cuore, Rome, Italy

${ }^{2}$ Department of Woman and Child Health and Public Health - Public Health Area, Fondazione Policlinico Universitario A. Gemelli IRCCS, Rome, Italy

Full list of author information is available at the end of the article
}

C The Author(s). 2021 Open Access This article is licensed under a Creative Commons Attribution 4.0 International License, which permits use, sharing, adaptation, distribution and reproduction in any medium or format, as long as you give appropriate credit to the original author(s) and the source, provide a link to the Creative Commons licence, and indicate if changes were made. The images or other third party material in this article are included in the article's Creative Commons licence, unless indicated otherwise in a credit line to the material. If material is not included in the article's Creative Commons licence and your intended use is not permitted by statutory regulation or exceeds the permitted use, you will need to obtain permission directly from the copyright holder. To view a copy of this licence, visit http://creativecommons.org/licenses/by/4.0/. The Creative Commons Public Domain Dedication waiver (http://creativecommons.org/publicdomain/zero/1.0/) applies to the data made available in this article, unless otherwise stated in a credit line to the data. 


\section{Background}

Head and neck cancer (HNC) is a group of cancers that occur in oral cavity, pharynx and larynx, it is the sixth most common cancer, with approximately 650.000 new cases and 300.000 deaths annually [1]. Although the overall survival-rate after the primary HNC have increased [2] due to an improved diagnosis and therapeutic approaches, the incidence of second primary cancer (SPC) remains one of the main long-term causes of mortality [3, 4]. It is estimated that approximately 15-25\% of HNC patients develop SPCs within five years of initial diagnosis $[5,6]$. The main risk factors associated with the development of SPC in HNC survivors include environmental factors such as tobacco use, alcohol consumption, and human papillomavirus infection, as well as genetic factors [1]. With advancements in genetics and genomics, especially with DNA sequencing, genetic factors have become increasingly studied for their potential role in the development of HNC [7]. The affected genes are responsible for normal cell growth, DNA-repair, cell-cycle control, programmed cell death (apoptosis), cell differentiation and oxidative stress [8]. Genome wide association studies (GWAS) have already demonstrated important associations between several genetic abnormalities and HNC carcinogenesis $[9,10]$. Although single nucleotide polymorphisms (SNPs) have been widely studied for a potential increased susceptibility to HNC development $[11,12]$, there is still no consistent evidence about the effect of SNPs among HNC patients into developing SPCs. Identification of genes and genetic markers associated with poor survival after HNC may distinguish patients with increased SPC risk, facilitating surveillance and enabling targeted interventions while reducing mortality [13]. Therefore, it is important to identify pathways of carcinogenesis that might serve as potential markers for identification of patients at high risk of developing SPC after primary HNC. To address this issue, we aimed to review and analyze the available literature and identify the SNPs that contribute to SPC development among HNC patients and to provide quantitative assessment of the associations between SNPs and SPC risk.

\section{Methods}

This systematic review was conducted and reported based on the Preferred Reporting Items for Systematic Reviews and Meta-analysis Protocol (PRISMA-P) checklist [14] (Additional file 1). The protocol of this research was registered on International prospective register of systematic reviews database (PROSPERO) with the registration number CRD42019135612.

\section{Eligibility criteria}

Studies were considered eligible for inclusion if they evaluated the association between SNPs and SPC risk in
HNC patients, and if they provided the effect measures with the corresponding 95\% confidence interval (CI). Studies reporting primary data were included. There were no restrictions on primary HNC stage or treatment status. According to Warren and Gates criteria, a SPC is defined as a second cancer that developed after a primary cancer, that is of non-squamous cell origin, or which has developed in a different location other than the primary cancer. If the second cancer is of squamous cell origin and has developed in the same region as the primary cancer, it is only coded as an SPC if more than 60 months had passed since the primary cancer diagnosis [15]. Therefore, outcomes such as recurrences, metastases or multiple primary cancers were excluded from this review. Studies were also excluded if they reported genetic alterations such as microsatellite instability or genetic variants over-expression. Editorials, comments, conference papers, narrative reviews, case reports, case series and descriptive cross-sectional studies were also excluded.

\section{Search strategy}

Two researchers [IH; VV] systematically searched PubMed, Scopus and ISI Web of Science online databases for eligible studies published in English from inception until January 31st, 2020. The following search query was used in PubMed: (((Head and Neck) OR pharynx OR pharyngeal OR oropharynx OR oropharyngeal OR hypopharynx OR hypopharyngeal $O R$ nasopharynx $O R$ nasopharyngeal $O R$ larynx OR laryngeal OR (oral cavity) OR (upper aerodigestive tract) OR UADT) AND (tumor OR neoplasm* OR cancer OR malignanc* OR carcinoma)) AND ((second primary) $O R$ SPC) AND ((genetic AND (characterization OR alterations $O R$ variant $O R$ polymorphism)) OR gene $O R$ microRNA OR SNP OR (single nucleotide polymorphisms) OR polymorphism* OR biomarker*).

Other two databases were searched using the appropriately modified PubMed search query (details are available upon request).

Subsequently, the reference lists of the included studies were manually searched for additional relevant publications. In the second step, aiming to understand whether GWASs identified any genetic loci associated with the risk of SPC in HNC patients, we also explored the following GWAS databases: GWAS Central National Human Genome Research Institute (NHGRI GWAS Catalog) [16], The database of Genotypes and Phenotypes (dbGaP) [17]; The GRASP: Genome-Wide Repository of Associations Between SNPs and Phenotypes, and The genome wide association database (GWAS DB) [18].

\section{Study selection}

Identified studies from all databases were uploaded to Mendeley Reference Manager and duplicate articles were 
removed. Two independent researchers $[\mathrm{IH} ; \mathrm{VV}]$ performed the first screening based on titles and abstracts. In the second stage of screening, studies with full texts available were carefully reviewed. Studies that met the eligibility criteria were selected for inclusion. The PRIS MA flow chart was created, reporting all the steps of search strategy and study selection: total number of studies retrieved, number of excluded studies during title/abstract screening, and number of studies excluded during full-text assessments, along with reasons of exclusion. Disagreements were resolved through discussion with the third researcher [RP] until the consensus was reached.

\section{Data extraction}

From each of the included studies, two researchers [IH; $\mathrm{VV}$ ] independently extracted the following data: first author, year of publication, study design and setting, study size, patients' ethnicity, primary HNC site, follow-up period, number of patients with SPC, SPC site(s), genes, chromosomes, SNPs, measure of association and corresponding genetic model. Researchers double-checked the extracted data and few subsequent discrepancies were resolved through discussion and in consultation with another researcher [RP].

\section{Quality assessment}

Two researchers $[\mathrm{IH} ; \mathrm{VV}]$ independently assessed quality of the included studies using the Q-Genie tool, which was specifically designed for the evaluation of genetic association studies [19]. This tool contains 11 items, assessing: rationale for conducting the study, selection and definition of outcome of interest, selection and comparability of comparison groups, technical and nontechnical classification of the exposure, other source of bias, appropriateness of sample size and power, description of the analyses and statistical methods used, testing of assumptions and appropriateness of inferences drawn from results. Each item is rated on a 7-point scale: "1 point - poor"; "2 and 3 points - good"; "4, 5 and 6 points - very good" and "7 - excellent". For studies with control group, the overall quality of studies is categorized as the following: "poor quality" if score $\leq 35$; "moderate quality" if score $>35$ and $\leq 45$; and a "good quality" if score $>45$. For studies without control groups, values for each of the categories listed are $\leq 32 ;>32$ and $\leq 40$; and $>40$, respectively. Any disagreement was solved through discussion with the third researcher [RP].

\section{Data synthesis and analysis}

The main findings were reported in a tabular synthesis, separately for each SNP, and the qualitative synthesis reported possible associations of each SNP with the SPC risk. Meta-analysis was performed considering different study designs, and the SNPs studied reported in each study. When at least two studies on the same SNP were available and evaluated the same genotype model, the data were pooled in a random-effect meta-analyses [20]. Effect size were expressed as hazard ratios (HR) or odds ratios (OR) with the corresponding 95\% confidence intervals (CI), as appropriate. We stratified the analyses according to the site of SPC. The heterogeneity between studies was assessed using the $\mathrm{X}^{2}$-based Q-statistics and the $I^{2}$ statistics [21]. The heterogeneity was considered low if the $I^{2}$ value was < $25 \%$. $P$-values of less than 0.05 were considered statistically significant. To assess the presence of publication bias (where appropriate), we conducted Egger's asymmetry test (level of significance $p<0.05$ ) for the SNPs with at least three pooled studies [22]. Statistical analyses were performed using the Stata software package version 13 (StataCorp. College Station. Texas).

\section{Results \\ Search results}

The initial search of PubMed, ISI Web of Science and Scopus databases identified a total number of 3053 articles. After removing the duplicates, 2635 articles were screened by title and abstract. One hundred fortyseven full-text articles were evaluated, of which twentyone articles met the inclusion criteria. No additional studies were included after checking the reference lists of the included articles. The entire process of the literature search and study selection is reported in details in the PRISMA Flowchart in Fig. 1. From the search of GWAS databases, we did not find any GWAS on genetic loci associated with a risk of SPC in HNC patients.

\section{Characteristics of the studies}

Characteristics of the twenty-one included studies [23-43] are reported in Table 1. Sixteen studies were of cohort study design and five were case-control studies, published from 2005 to 2019. Eighteen studies were conducted in the USA, seventeen of which retrieved patients from the same randomized placebocontrolled trial [44], investigating different genes and SNPs. The remaining three studies were performed in Canada, United Kingdom and Italy. The number of HNC patients included in the cohort studies varied from 215 to 1529. The majority of patients were male. Median followup time varied from 2.1 to 5.21 years. Studies conducted in the USA reported data on the ethnicity where most patients were of non-Hispanic white ethnicity. Regarding primary $\mathrm{HNC}$ site, twenty studies evaluated all HNC sites (oral cavity, larynx, pharynx), whereas the study by Gal et al. [28] investigated only oral cavity site. As for the SPC site, twelve studies reported data on tobacco-related SPC (esophagus, lung or bladder) and on non-tobacco-related 


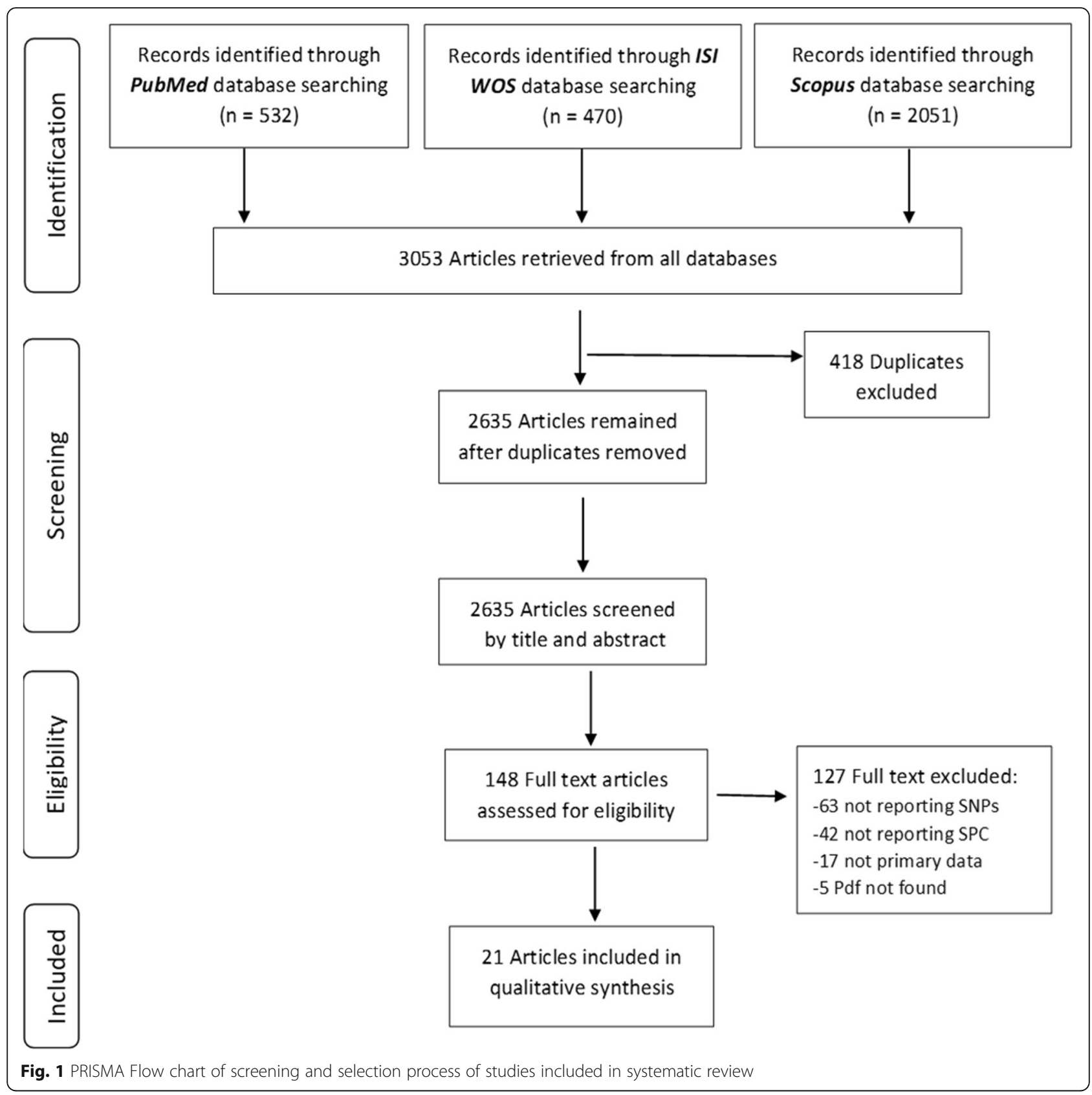

SPC (prostate, thyroid or colon); while nine remaining studies did not report site-specific data.

Fifty-one genes (p53, GST, $p 73, p 21, E R C C 5, M D M 4$, MMP21, GSTM5, BCCIP, TNKS1BP1, RAD54L, CAD9, CDK8, FAS, JAK2, P27, SLC31A1, DNMT3B, MDM2, P14ARF, MMP3, RXRA, TSC1, CDC25C, FASL, FLT3, CASP3, KRAS, RGS5, BCL2L2, GPX1, MKI67, MNAT1, RNASEN, IGF1R, PDGFB, TNFRSF10B, CDK6, AXIN, XPO5, CAT, GLI2, CFTR, RGS11, GSTM4, IL1R1, NR1I2, NHEJ1, SMC1B, SSTR2, RNF2) were reported to have significant associations with the SPC risk. Overall, the most investigated genes were GST gene family (five studies), $p 53$ (four studies), $p 73$ (three studies), and by 2 studies each of the following genes $p 21, F A S$ and $F A S L$, and XPD (ERCC2). A total of 122 different SNPs were explored, of which 81 SNPs were significantly associated with the SPC risk, in particular with an increased risk. Data for the investigated SNPs are reported separately, according to the study design. The SNPs investigated in cohort studies are reported in Table 2, whereas the SNPs evaluated in case-control in case-control studies are reported in Table 3. The GST gene family polymorphisms explored were GST-M1, GST-T1 and GST-P1. GSTM1 null genotype was associated with an increased risk 


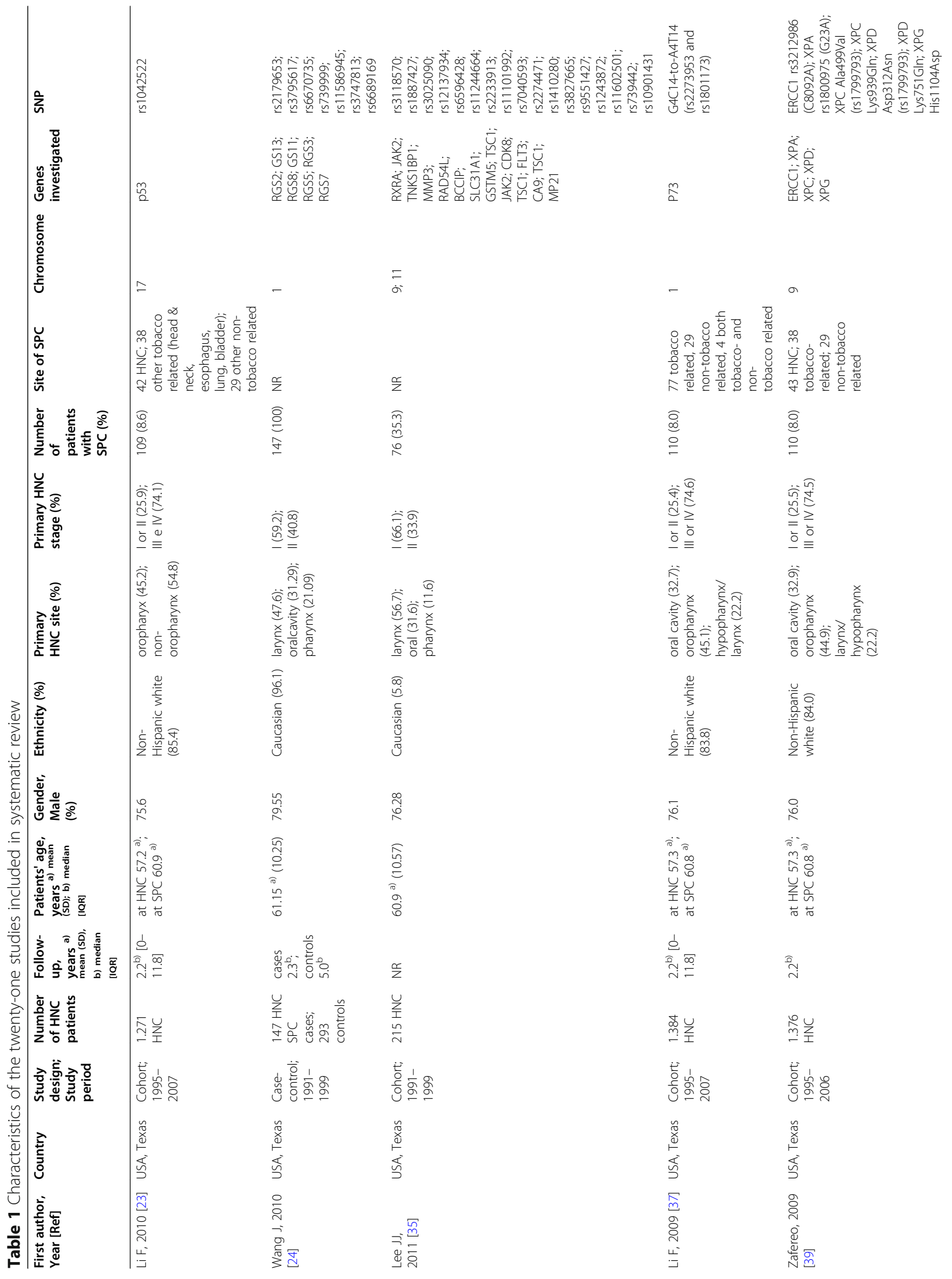




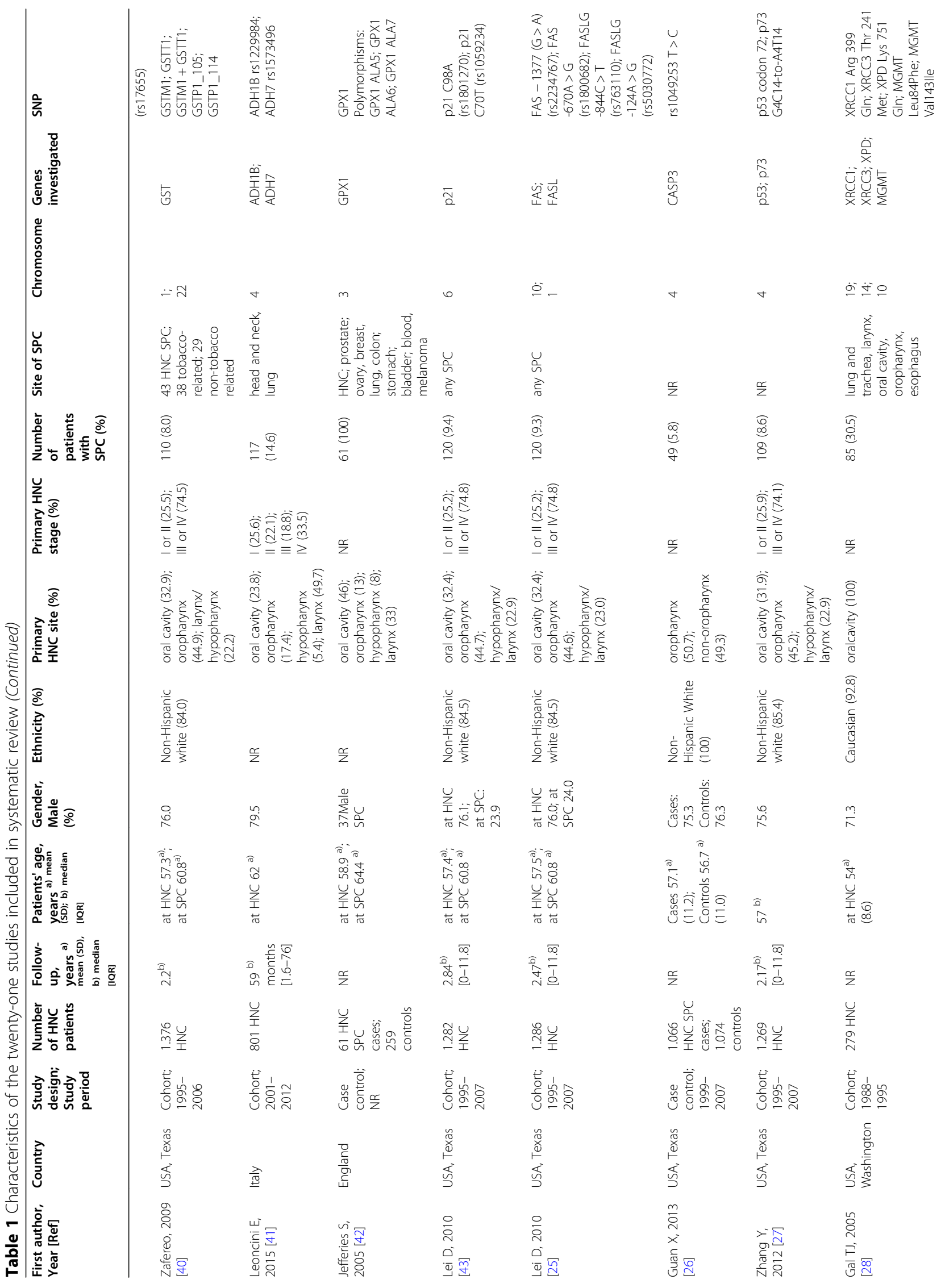




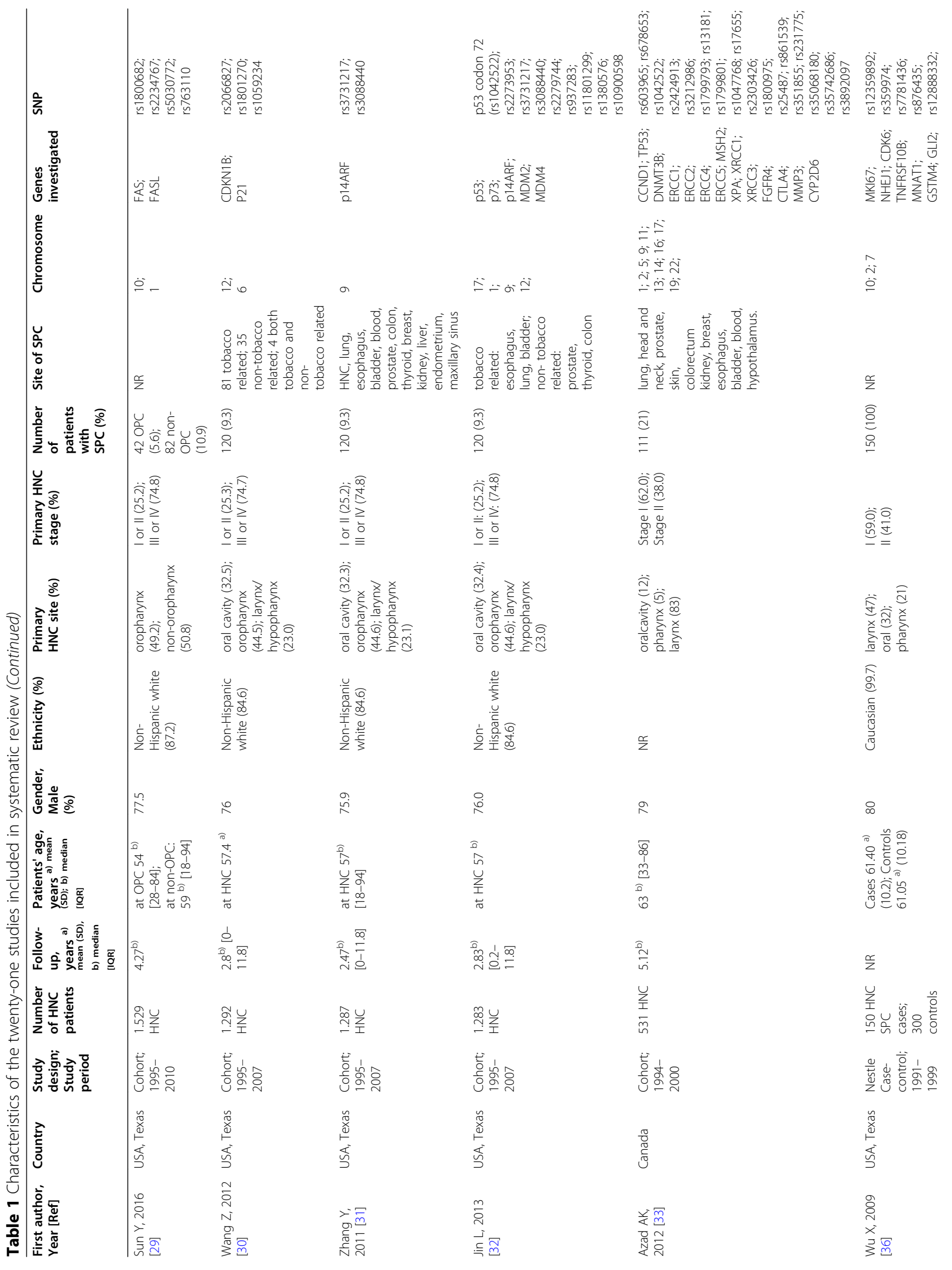




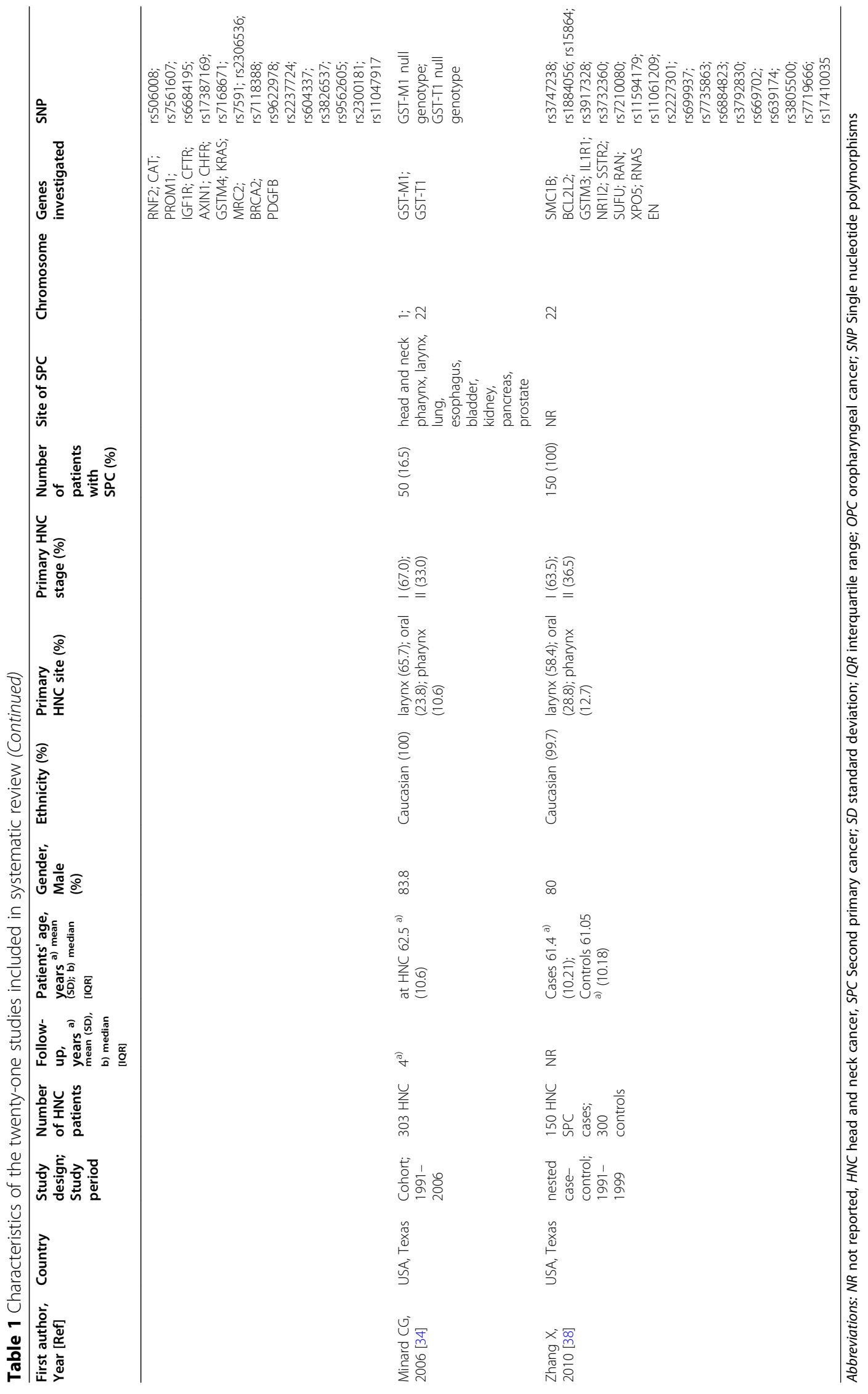




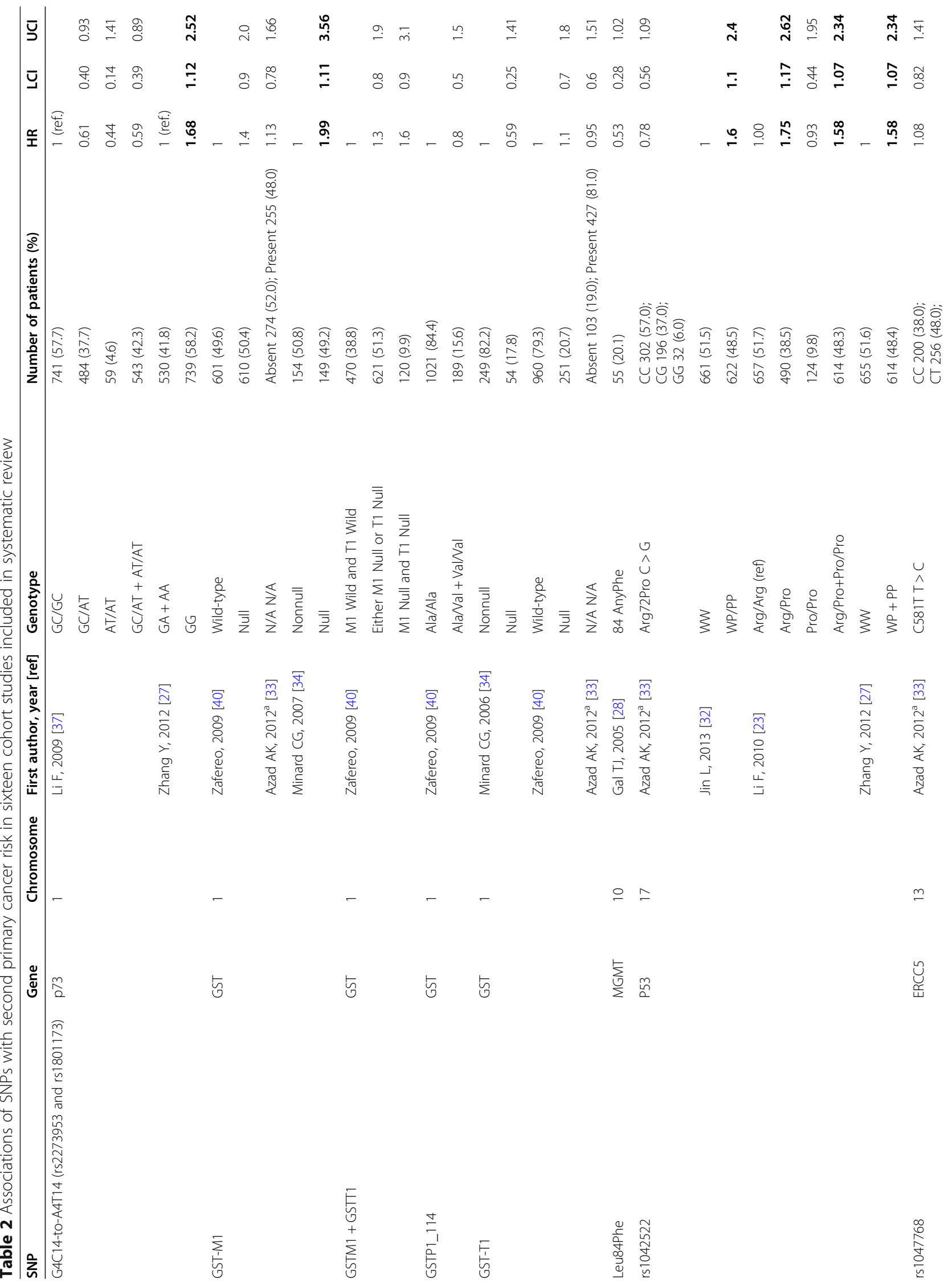




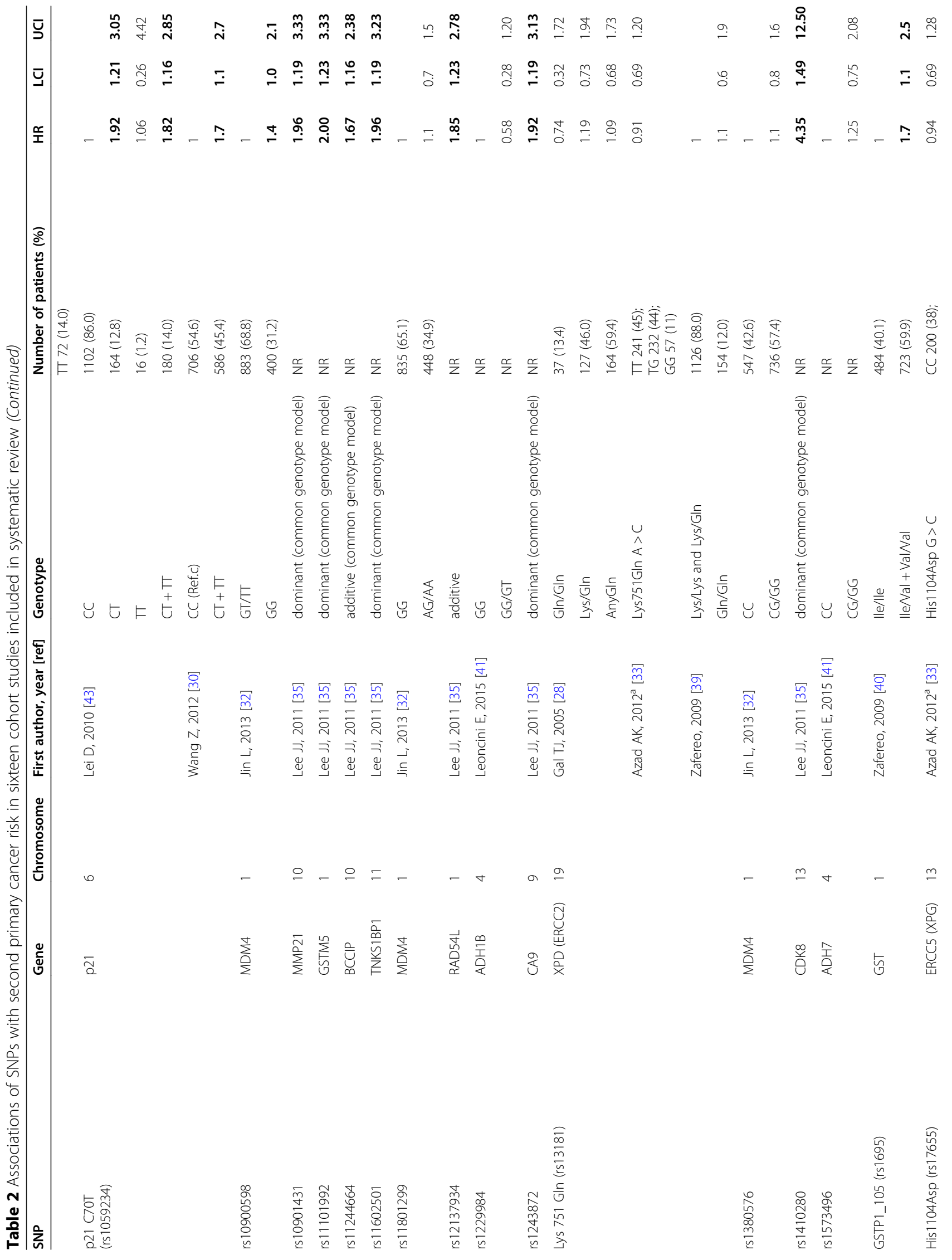




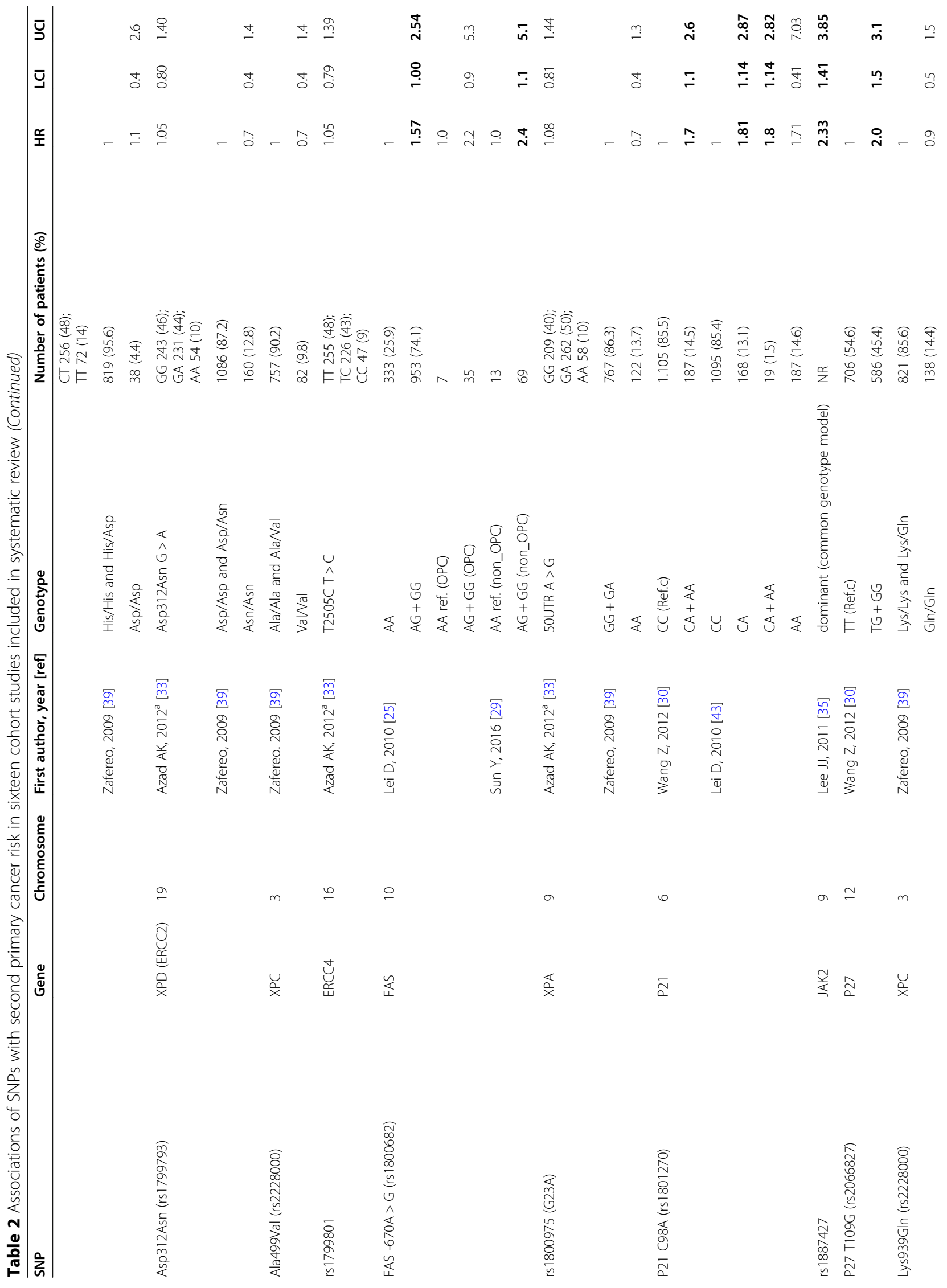




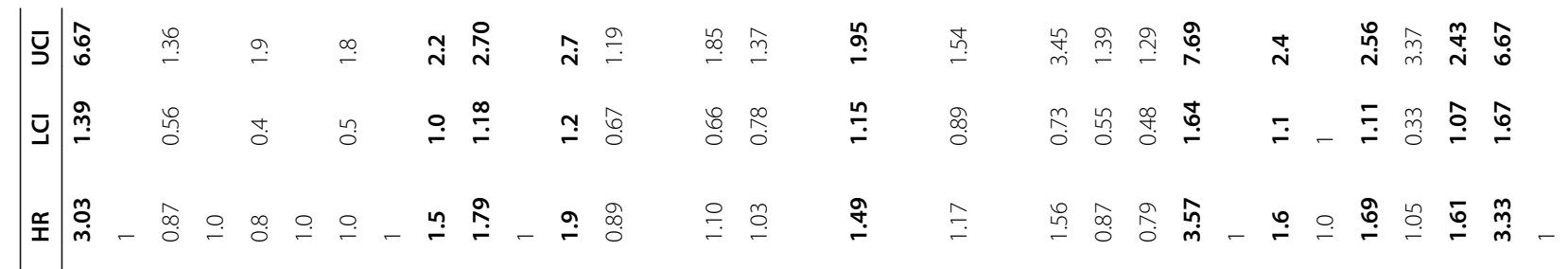

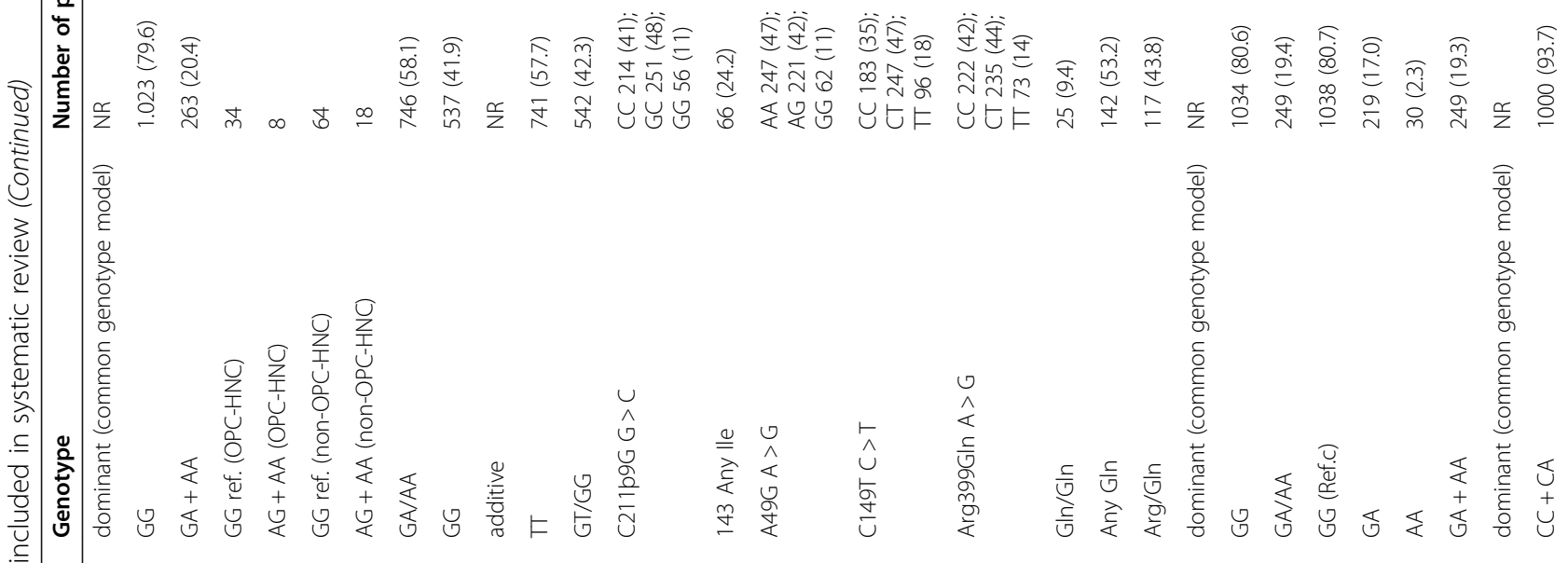

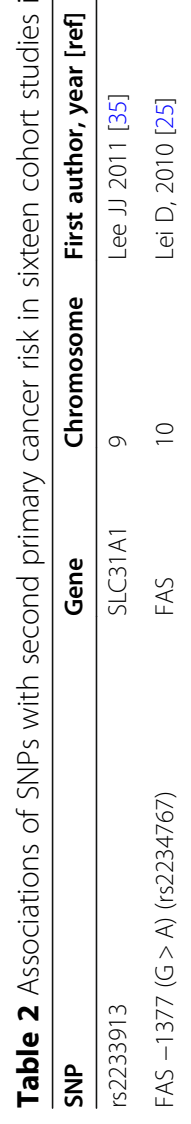

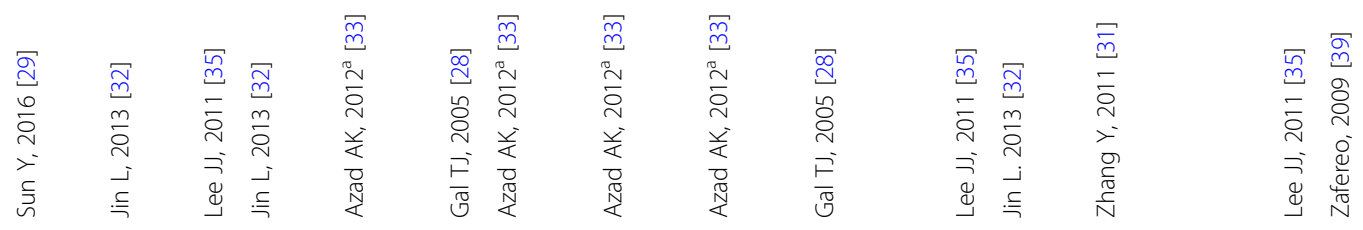

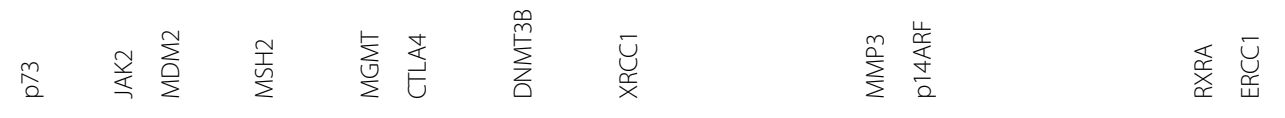

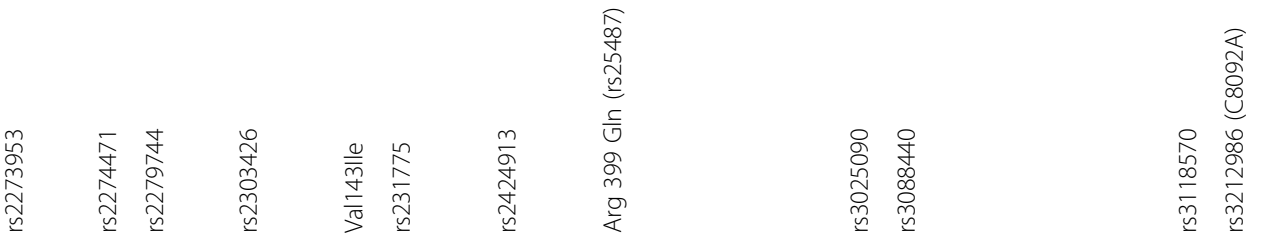




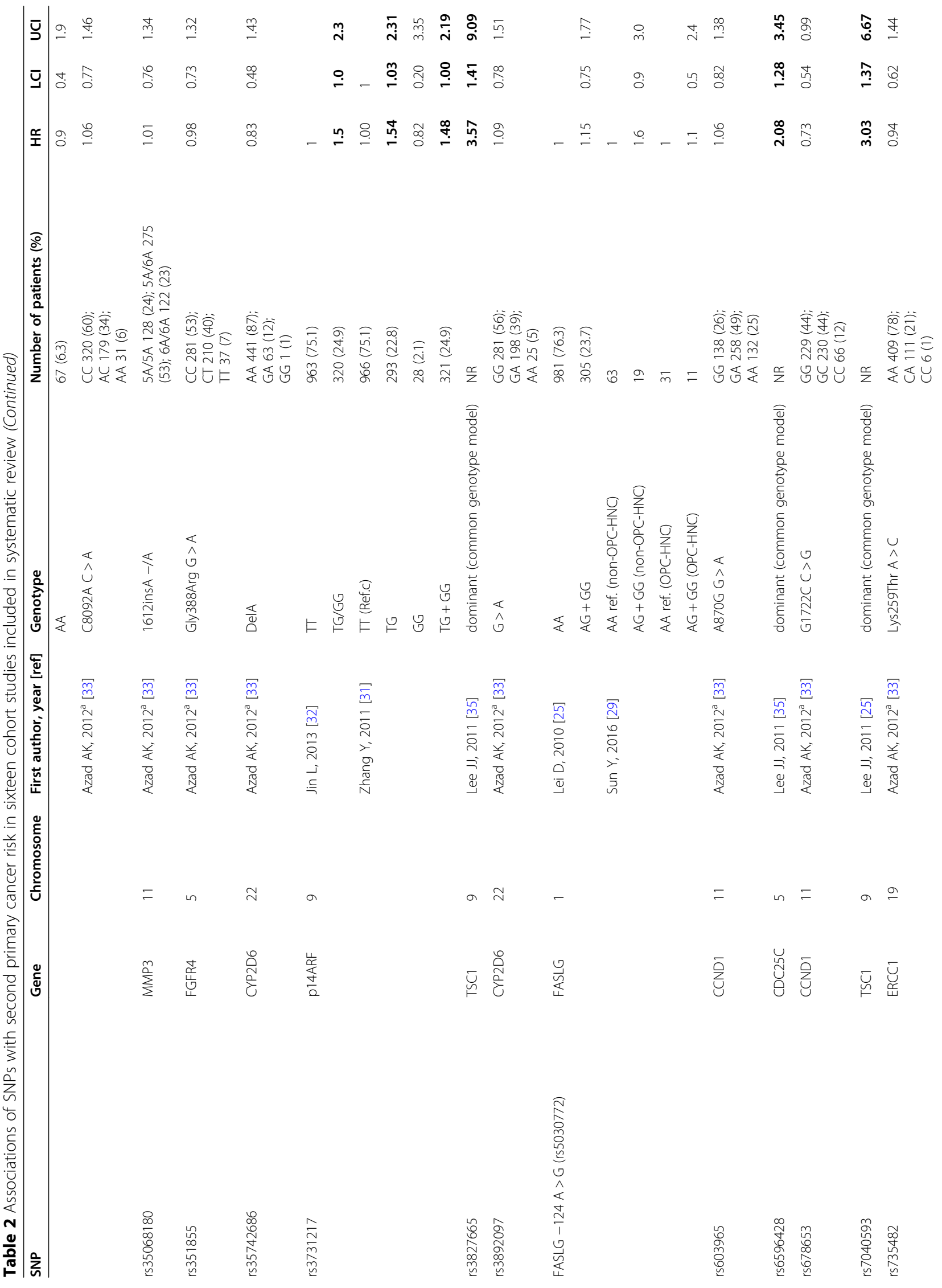


$\begin{array}{ll}\text { Hoxhaj et al. BMC Cancer } & \text { (2021) 21:660 }\end{array}$

Page 14 of 24

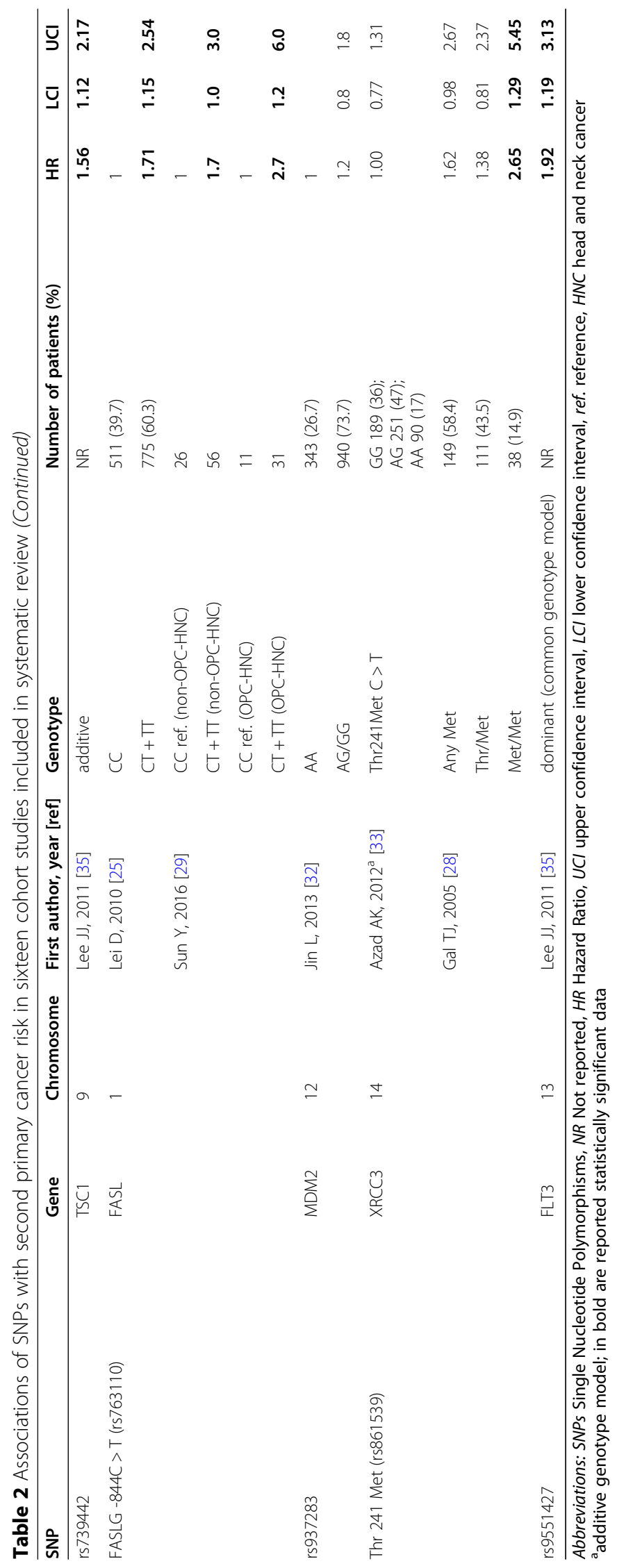




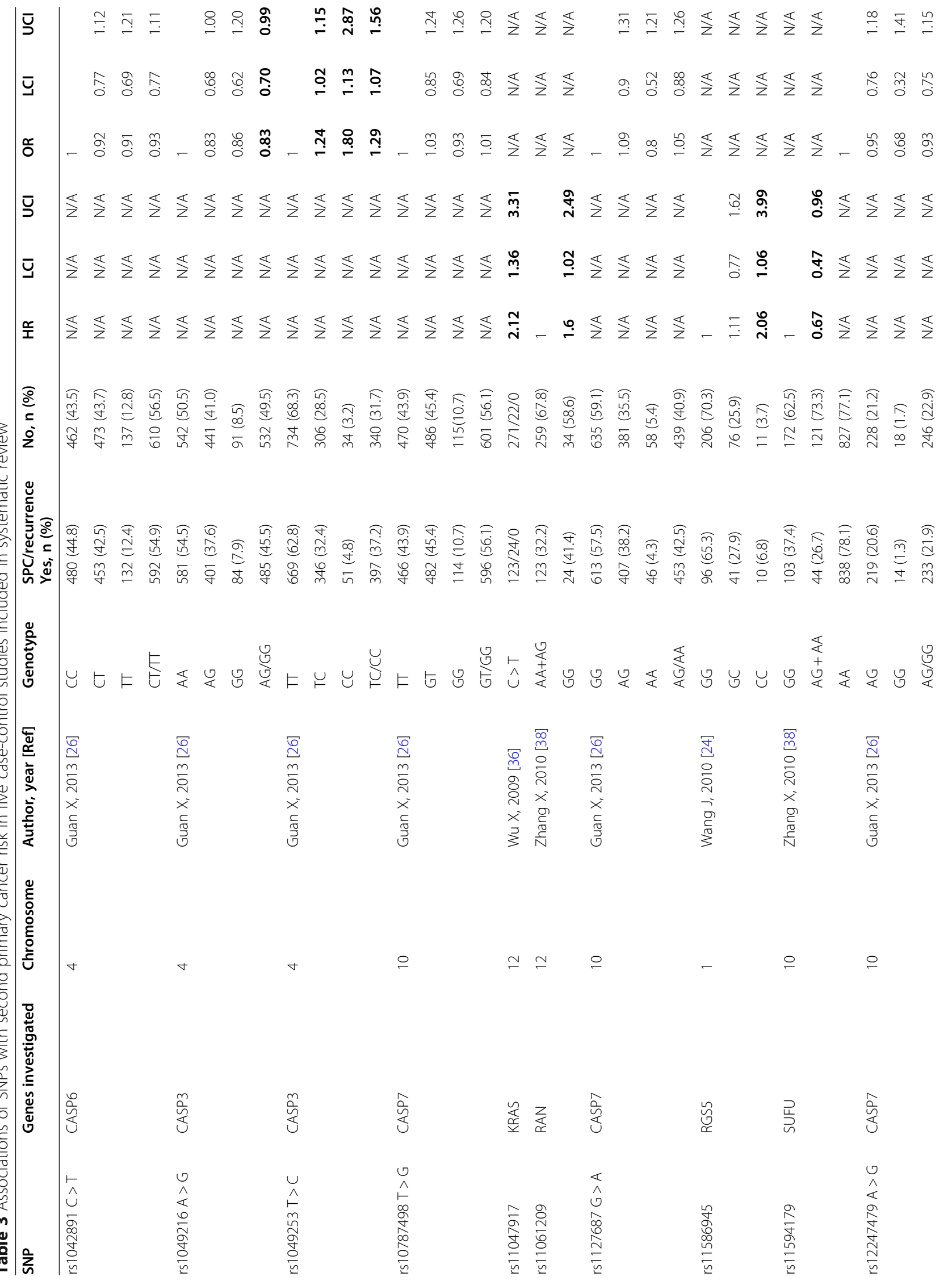




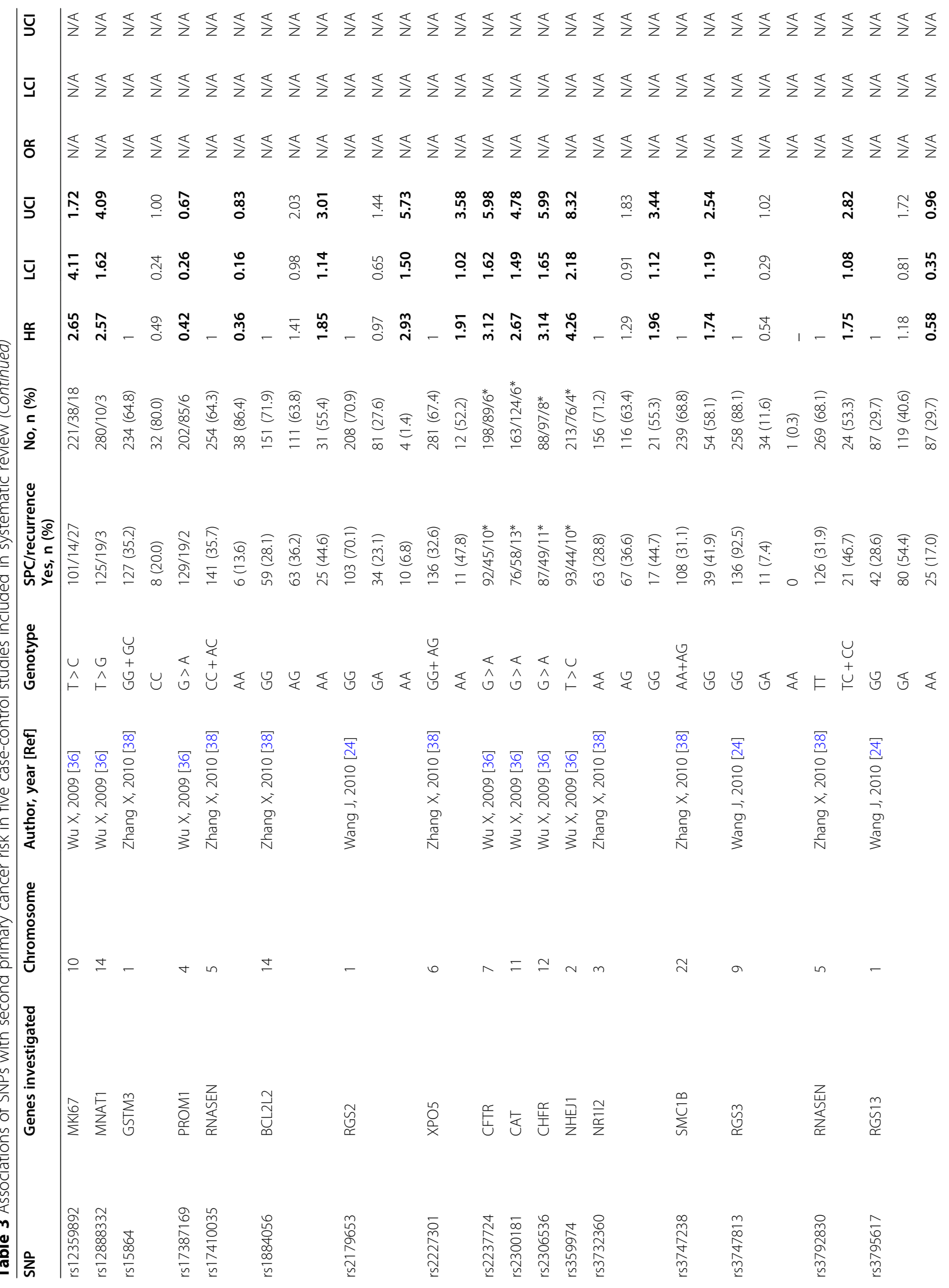




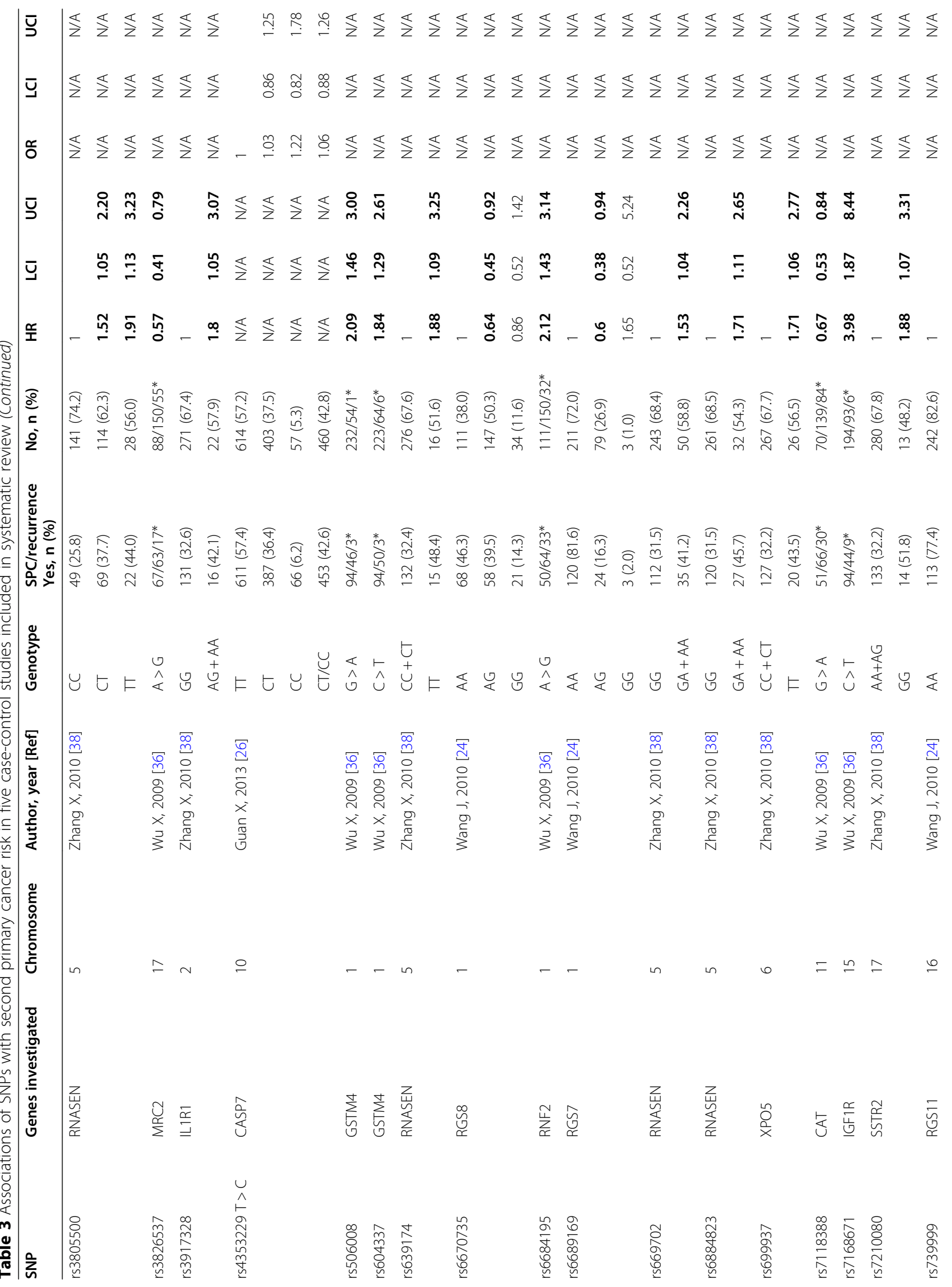




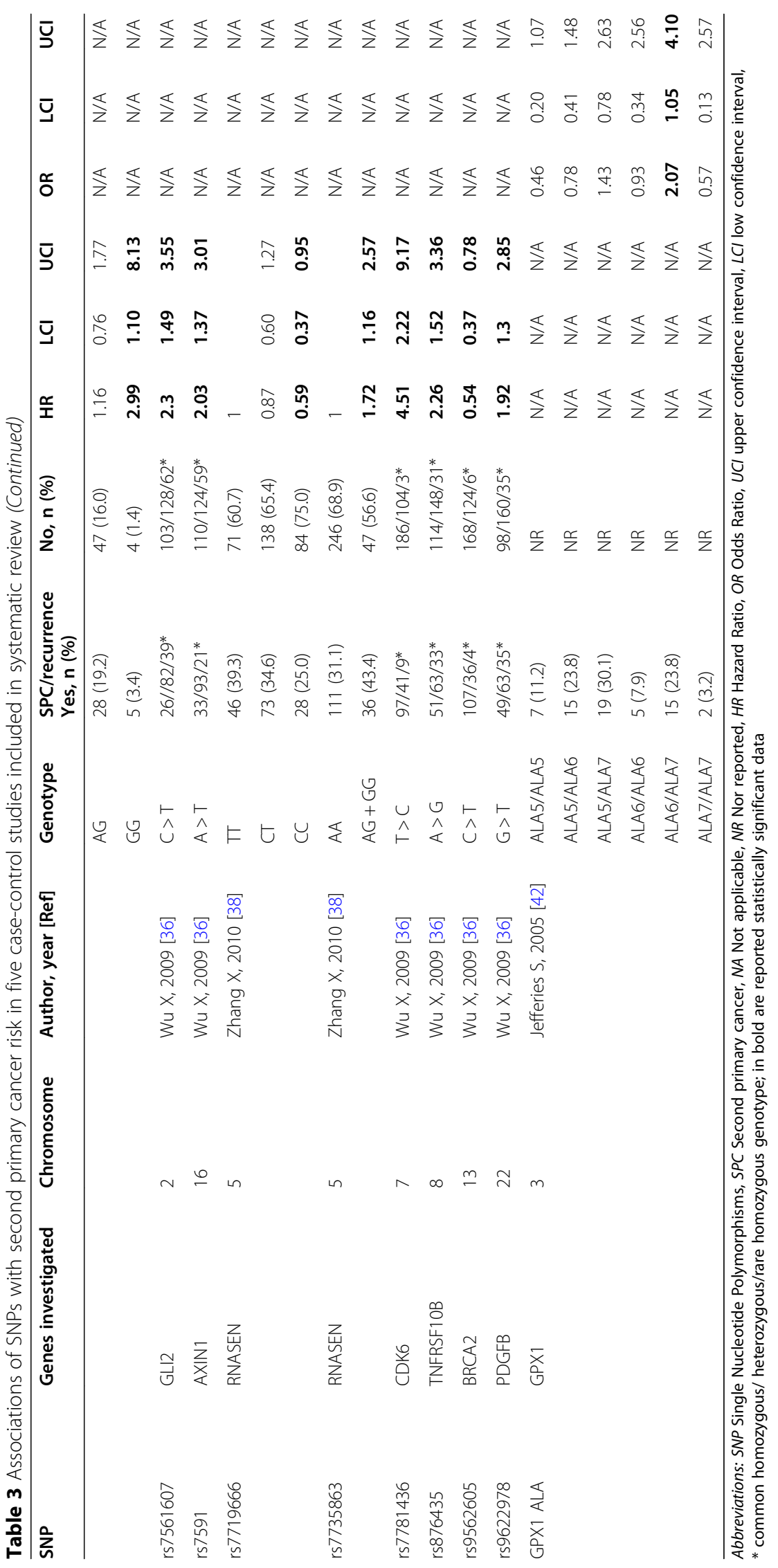




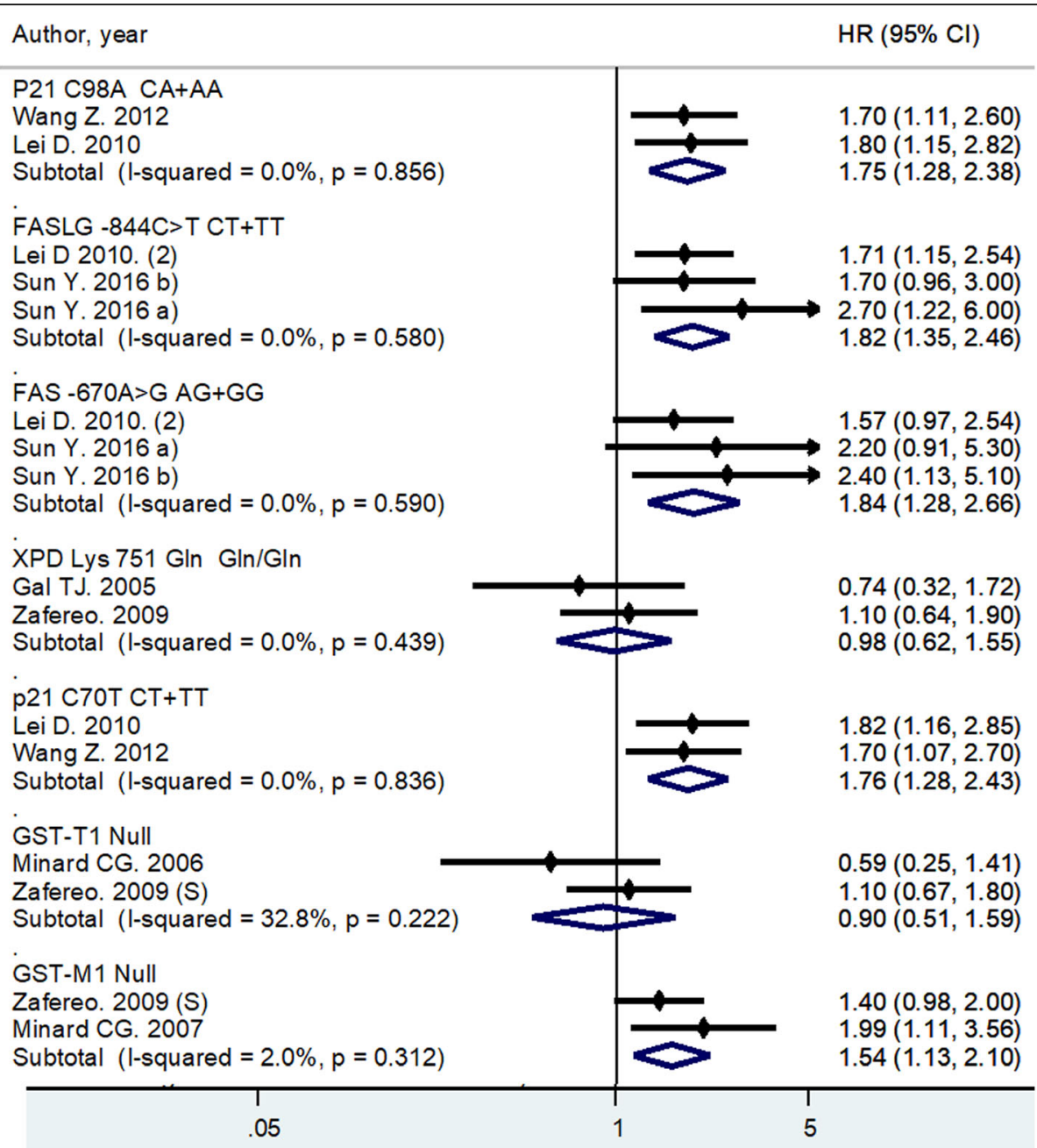

Fig. 2 Forest plot on associations of seven Single Nucleotide Polymorphisms with Second primary cancer risk in HNC patients

for any SPC $(\mathrm{HR}=1.99 ; 95 \% \mathrm{CI}: 1.11-3.56)$ and for tobacco-related SPCs $(\mathrm{HR}=2.16 ; 95 \% \mathrm{CI}: 1.01-4.62)$, whereas the GST-T1 null genotype demonstrated statistically non-significant protective effects for the SPC development ( $\mathrm{HR}=0.59 ; 95 \% \mathrm{CI}: 0.25-1.41)$. Patients with both GST non null genotypes were 0.52 times less likely (95\% CI: $0.28-0.96$ ) to develop a SPC compared to participants who had the GST-M1 null and GST-T1 non null genotypes. Patients with the GSTP1 gene Ile105Val polymorphism had a 1.7-fold elevated risk for developing SPC compared to patients with the wild-type genotype $(\mathrm{HR}=1.7 ; 95 \% \mathrm{CI}: 1.1-2.5)$. The combined risk of GSTP1 gene 105 and GSTP1 114 polymorphisms, increased SPC risk, suggesting that two polymorphisms may have a joint effect on the risk of SPC development [40].

The $p 53$ gene rs 1042522 polymorphism was explored by four studies, of which three reported significant association for increased SPC risk. Patients with $p 53 \mathrm{WP}+$
PP genotype [27] and patients with p53 72 Arg/Pro genotype [23] had an increased SPC risk. Patients with the combined $p 53$ variant (Arg/Pro + Pro/Pro) genotypes, and patients with the combined polymorphisms $p 53$ codon 72 and $p 73$ G4C14-to-A4T14 [27], had a significantly increased SPC risk.

The $p 21$ gene C98A and C70T polymorphisms genotypes were distributed significantly different between patients who developed SPC and those who did not. Patients with p21 $98 \mathrm{CA} / \mathrm{AA}$ and p21 $70 \mathrm{CT} / \mathrm{TT}$ variant genotypes had a significantly increased SPC risk [30, 43]. The combined effect of both p21 polymorphisms together on SPC risk, showed that patients with either variant allele ( $p 2198$ A or $p 2170 \mathrm{~T}$ ) had a 2-fold increased SPC risk compared with patients with the combined $p 2198 \mathrm{CC}$ and $p 2170$ CC wild-type genotypes [30, 43].

The FAS gene polymorphism showed that the SPC risk differed according to the index $\mathrm{HNC}$ site. Patients with index OPC and FASL $844 \mathrm{CT} / \mathrm{TT}$ genotype had 
significantly increased SPC risk (aHR, 2.7; 95\% CI: $1.2-$ 6.0, $p=0.032$ ) while index non-OPC patients with FAS670 AG/GG and FasL844 CT/TT genotypes had significantly increased risk of SPC (aHR, 2.4 and 1.7; 95\% CI, 1.1-5.1 and 1.0-3.0; and $p=0.043$ and 0.049, respectively). Patients carrying more FAS/FASL variants had significantly increased risk of SPC among index nonOPC patients [29]. Overall, a non-site-specific increased SPC risk in patients with FAS $-670 \mathrm{AA}$ and the FASLG -844 CC genotypes was also reported by Lei $\mathrm{D}$ et al. [25], which further showed an increased SPC risk, in a doseresponse manner, with the combined risk genotypes, of four polymorphisms on the SPC risk.

The XPD gene Lys751Gln polymorphism carriers had a non-significant reduced SPC risk $[28,39]$. The study by Zafereo et al. [39] did not find a significant SPC risk also in stratified analysis by SPC type. However, when they combined XPD gene Lys751Gln polymorphism with other six SNPs of the core genes in the nucleotide excision repair (NER), in a dominant model there was a trend for increased SPC risk with increasing number of risk genotypes [39].

\section{Quality assessment}

Results of the quality assessment of the included studies are reported in Additional file 2. Among fifteen studies without group control, only the study by Wang et al. [24], had moderate quality, while the others were of good quality. The study by Wang et al. [24] had moderate quality due to the scarcity in disclosure of potential sources of bias and for not testing of assumption and inferences for genetic analyses. Six studies with group control were of moderate quality, mostly because of the poor non-technical classification of the exposure, and for not testing of assumption and inferences for genetic analyses.

\section{Meta-analysis}

Seven cohort studies, that reported the same genotype of the same SNP in at least two studies, were included in the meta-analysis. The included SNPs and their genotypes were $p 21$ C70T, CT + TT genotype; FASLG $-844 \mathrm{C}>\mathrm{T}$, CT + TT genotype; $P 21$ C98A, CA + AA genotype; FAS gene -670A > G; GST-M1, Null genotype; GST-T1, Null genotype; and XPD Lys $751 \mathrm{Gln}$, Gln/Gln genotype.

All the studies included in the meta-analysis adjusted the estimates for age, sex, smoking and alcohol [25, 29, $30,34,39,40,43]$. Some of the studies adjusted also for other variables: ethnicity $[25,29,30,39,40,43]$, treatment [29, 34] and primary HNC site [28, 29, 34].

The associations between SNPs and SPC risk, stratified by SNP, are shown in the Forest plot in Fig. 2. Pooled analysis revealed five SNPs with a statistically significant increased SPC risk: p21C70T, CT + TT genotype $(\mathrm{HR}=$
1.76; 95\% CI: $\left.1.28-2.43 ; I^{2}=0.0 \%\right) ;$ FASLG $-844 \mathrm{C}>\mathrm{T}$, $\mathrm{CT}+\mathrm{TT}$ genotype $\left(\mathrm{HR}=1.82 ; 95 \% \mathrm{CI}: 1.35-2.46 ; I^{2}=\right.$ $0.0 \%)$; $211 \mathrm{C} 98 \mathrm{~A}, \mathrm{CA}+\mathrm{AA}$ genotype variant $(\mathrm{HR}=1.75$; 95\% CI: $\left.1.28-2.38 ; I^{2}=0.0 \%\right) ; F A S-670 \mathrm{~A}>\mathrm{G}(\mathrm{HR}=1.84$; 95\%CI: $\left.1.28-2.66 ; I^{2}=0.0 \%\right)$ and GST-M1, Null genotype variant $\left(\mathrm{HR}=1.54 ; 95 \% \mathrm{CI}: 1.13-2.10 ; I^{2}=2.0 \%\right)$. A non-significant decreased SPC risk was associated with GST-T1, Null genotype variant $(\mathrm{HR}=0.90 ; 95 \% \mathrm{CI}$ : $\left.0.51-1.59 ; I^{2}=32.8 \%\right) ;$ and XPD Lys751Gln, Gln/Gln genotype variant $\left(\mathrm{HR}=0.98 ; 95 \% \mathrm{CI}: 0.62-1.55 ; I^{2}=\right.$ $0.0 \%$ ). In each of the pooled analysis there was no heterogeneity between studies. The Egger test demonstrated no statistical evidence of publication bias for funnel plot FASLG -844C $>\mathrm{T}(p=0.363)$ and FAS $-670 \mathrm{~A}>\mathrm{G}(p=0.24)$.

Stratified analysis according to the SPC site was possible for three SNPs: XPD Lys $751 \mathrm{Gln} / \mathrm{Gln}$; GST-T1 Null; and GST-M1 Null. There was a non-significant decreased risk for HNC squamous cell carcinoma SPC in patients with XPD Lys751Gln, Gln/Gln genotype (HR = 0.46; 95\% CI: $\left.0.17-1.25 ; I^{2}=25.1 \%\right)$. For tobacco-related SPC, the risk was decreased in GST-T1 Null carriers (HR $=0.83 ; 95 \%$ CI:0.48-1.43; $\left.I^{2}=0.0 \%\right)$. and increased in GST-M1 Null carriers (HR $=1.53$; 95\% CI:0.96-2.44; $\left.I^{2}=18.4 \%\right)$, although the associations did not reach the level of significance (Additional file 3).

\section{Discussion}

This systematic review on genetic associations of SPC development after primary HNC included twenty-one studies and reported fifty-one genes with a significantly increased SPC risk. These genes were involved in different carcinogenesis pathways, including detoxification, DNA repair, apoptosis or cell cycle regulation, developmental pathway and cell adhesion. A total of 122 SNPs were investigated, of which eighty-one SNPs were significantly associated with an increased risk of SPC among HNC patients. Five SNPs ( $p 21 \mathrm{C} 70 \mathrm{~T}$, FASLG $-844 \mathrm{C}>\mathrm{T}, P 21$ C98A GST-M1 and GST-T1) were significantly associated with an increased SPC risk in our meta-analysis. Genes of these five SNPs are involved in different pathways of carcinogenesis, such as apoptosis process or cell cycle regulation, DNA repair mechanism and carcinogen detoxification processes [45, 46].

The $p 21$ gene C98A polymorphism, that resulted with a significantly increased SPC risk in our meta-analysis, causes a non-synonymous serine-to-arginine substitution at codon 31 and has been reported to contribute to genetic susceptibility to cancer, including HNC [47], endometrial [48] and breast cancer [49]. The influence of $P 21$ gene polymorphisms in cancer risk, including $\mathrm{HNC}$, has been reported previously $[47,50,51]$.

FAS $-670 A>G$ and FASLG -844 T/C polymorphisms have been previously associated with an increased risk of HNC [52], gynecological cancer [53] and esophageal 
squamous cell cancer [54], whereas FAS $-670 \mathrm{~A}>\mathrm{G}$ has been also associated with an increased risk of recurrence and death in epithelial ovarian cancer patients [53]. FAS and FASLG genes have a crucial role in apoptosis processes and their polymorphisms have been reported to affect the risk of cancer, including SPCs [55]. These polymorphisms modified the risk of SPCs differently for index OPC from non-OPC patients [29], suggesting that primary cancer site may contribute to the association of apoptosis and SPC risk. The significant associations of FAS/FASL variant genotypes with the increased SPC risk in those HNC patients ever smokers or ever drinkers might suggest that genetic factors, within the context of previous or continued exposure to smoking and alcohol consumption may affect the risk of SPC development [29].

GST-M1 null genotypes and GST-M1 null genotypes have been previously associated with an increased risk of HNC [56] and lung cancer [57], respectively. GSTs genes, having a crucial role in carcinogen detoxification, have been associated with an increased risk of HNC, skin, breast, lung and bladder [58]. The XPD Gln751Lys polymorphism had no significant association with a reduced SPC risk from our meta-analysis, despite the fact that XPD gene, acting as a key DNA repair protein in the NER pathway, is involved in cancer pathogenesis.

Despite the abundant evidence about the SNPs associated with the risk of primary HNC and the biological pathways, their genetic associations with the SPC risk and the carcinogenesis pathways, in particular in HNC patients, are still not sufficiently explored, and none GWAS has addressed this susceptibility. To our knowledge, there were not publicly available data from GWAS on the genetic associations of the seven SNP included in our meta-analysis with the development of any SPC.

There are some limitations in our study that should be pointed out. We included only studies published in English, therefore some studies in other languages or currently unpublished data might have been missed, indicating the possibility of publication bias. The majority of studies included in the systematic review investigated different SNPs in the same cohort of patients, thus the SNPs included in the meta-analysis were identified by only two primary studies. The stratified analysis according to smoking, alcohol status, treatment, or primary HNC site, were conducted in only few studies, that were not the ones included in our meta-analysis. The estimates of association may be biased due to the lack of this information.

Although data were pooled in the meta-analysis according to the genotype variant, it was not possible to identify the best genetic model for each SNP, because not all the studies reported genotype data that could enable us to calculate the estimates according to a genetic model. The results may vary depending on the genetic model used in statistical significance, however still remains the uncertainty on the best genetic model for the association of interest.

Despite these limitations, we addressed the potential publication bias by exploring GWAS publicly available websites. Except one study of moderate quality, the other studies included in the systematic review, and also in the meta-analysis were of good quality. To our knowledge, this is the first systematic review and meta-analysis to summarize the studies on the genetic associations of SPC development after primary HNC. The large number of genes included in this systematic review, could serve as an import guide to the researchers to choose the genes that can be studied further in the future. However, the reported associations, in particular for the polymorphisms not included in the meta-analysis, need to be confirmed in future studies.

Studies included in the systematic review reported small number of HNC patients developing SPC due to the insufficient follow-up times. Therefore, GWASs, larger and well-designed studies with longer follow-up time, and further studies pathway-oriented on biological functions of the polymorphisms, are needed in order to improve our knowledge of the genetic associations that influence the SPC occurrence after a primary HNC. Furthermore, the combined effect of a panel of polymorphisms that act in the same carcinogen metabolizing pathway support the notion that SPC development after a primary HNC is a polygenic process. The effects of associations of these polymorphisms with the SPC risk might be amplified, suggesting that their further exploration may provide higher predictive estimates of association $[36,40]$. In HNC patients, genetic testing for these SNPs, with evidences on clinical validity and utility, might be helpful for the identification of high-risk patients for developing a SPC, leading to personalized approaches and an early diagnosis of SPC. Moreover, considering that both, HNC and SPC result from complex interactions of genetic variants and environmental factors, further studies should focus on these interactions in SPC development. Future studies should also investigate the influence of risk factors, such as tobacco smoking, alcohol consumption or HPV status, and different treatment modalities in overall and site-specific SPC risk.

\section{Conclusions}

The polymorphisms identified and summarized in this study may serve as a potential therapeutic targets or markers for genetic susceptibility to SPC after an index $\mathrm{HNC}$, that may further enhance the identification of high-risk groups of $\mathrm{HNC}$ patients, aiming to provide a personalized treatment for an improved prognosis and a better quality of life. 


\section{Abbreviations}

HNC: Head and Neck Cancer; SPC: Second Primary Cancer; Cl: Confidence Interval; HR: Hazard Ratios; OR: Odds Ratio; GWAS: Genome wide association studies; SNPs: Single nucleotide polymorphisms; OPC: Oropharyngeal cancer

\section{Supplementary Information}

The online version contains supplementary material available at https://doi. org/10.1186/s12885-021-08335-0.

Additional file 1. Preferred Reporting Items for Systematic Reviews and Meta-Analyses (PRISMA) Checklist.

Additional file 2. Quality assessment of the twenty-one studies included in the systematic review using Q-Genie Tool.

Additional file 3. Stratified analyses according to Second Primary Cancer site, for each SNP genotype.

\section{Acknowledgments}

The authors would like to thank Dr. Katina Aleksovska and Dr. Vittoria Colamesta, for their technical support in the initial phase of the present work.

\section{Authors' contributions}

SB conceptualized and designed the study. IH, W and RP participated in data search and collection. $\mathrm{IH}$ and RP contributed to data analysis and interpretation. $\mathrm{IH}$ and $\mathrm{W}$ participated in preparing the original draft of the manuscript. SB and RP edited and reviewed the final version of the manuscript. All authors have read and approved the published version of the manuscript.

\section{Funding}

SB received a funding from Università Cattolica del Sacro Cuore (university funds line D.3.1) to cover the journal fee of the publication. The funders had no role in study design, data collection and analysis, decision to publish, or preparation of the manuscript.

\section{Availability of data and materials}

The datasets used and/or analyzed during the current study are available from the corresponding author on reasonable request.

\section{Declarations}

Ethics approval and consent to participate

Not applicable.

\section{Consent for publication}

Not applicable.

\section{Competing interests}

The authors declare that they have no competing interests.

\section{Author details}

${ }^{1}$ Section of Hygiene, University Department of Life Sciences and Public Health, Università Cattolica del Sacro Cuore, Rome, Italy. ${ }^{2}$ Department of Woman and Child Health and Public Health - Public Health Area, Fondazione Policlinico Universitario A. Gemelli IRCCS, Rome, Italy. ${ }^{3}$ Center for Disease Control and Prevention, Institute of Public Health of Vojvodina, Novi Sad, Serbia.

Received: 16 October 2020 Accepted: 10 May 2021

Published online: 02 June 2021

\section{References}

1. Ferlay J, Colombet M, Soerjomataram I, Mathers C, Parkin DM, Piñeros M, Znaor A, Bray F. Estimating the global cancer incidence and mortality in 2018: GLOBOCAN sources and methods. Int J Cancer. 2019;144(8):1941-53. https://doi.org/10.1002/ijc.31937.

2. Liao LJ, Hsu WL, Lo WC, Cheng PW, Shueng PW, Hsieh CH. Health-related quality of life and utility in head and neck cancer survivors. BMC Cancer. 2019;19(1):425. https://doi.org/10.1186/s12885-019-5614-4.
3. Chen JH, Yen YC, Chen TM, Yuan KSP, Lee FP, Lin KC, et al. Survival prognostic factors for metachronous second primary head and neck squamous cell carcinoma. Cancer Med. 2017;6(1):142-53 Available from: https://pubmed.ncbi.nlm.nih.gov/27987269/. [cited 2020 Jul 22].

4. Hoxhaj I, Hysaj O, Vukovic V, Leoncini E, Amore R, Pastorino R, et al. Occurrence of metachronous second primary cancer in head and neck cancer survivors: A systematic review and meta-analysis of the literature. Eur J Cancer Care (Engl). 2020; [cited 2020 Sep 21]; Available from: https:// onlinelibrary.wiley.com/doi/full/10.1111/ecc.13255.

5. Zhang WL, Zhu ZL, Huang MC, Tang YJ, Tang YL, Liang XH. Susceptibility of Multiple Primary Cancers in Patients With Head and Neck Cancer: Nature or Nurture? Front Oncol. 2019;9:1275. https://doi.org/10.3389/fonc.2019.01275.

6. Denaro N, Merlano MC, Russi EG. Follow-up in Head and Neck Cancer: Do More Does It Mean Do Better? A Systematic Review and Our Proposal Based on Our Experience. Clin Exp Otorhinolaryngol. 2016;9(4):287-97 Available from: http://www.e-ceo.org/journal/view.php?doi=10.21053/ceo.2 015.00976. [cited 2018 Jul 31].

7. Michmerhuizen NL, Birkeland AC, Bradford CR, Brenner JC. Genetic determinants in head and neck squamous cell carcinoma and their influence on global personalized medicine. Genes and Cancer. 2016;7(5-6): 182-200. https://doi.org/10.18632/genesandcancer.110.

8. Hopkins J, Cescon DW, Tse D, Bradbury P, Xu W, Ma C, et al. Genetic polymorphisms and head and neck cancer outcomes: a review. Cancer Epidemiol Biomark Prev. 2008;17(3):490-9. https://doi.org/10.1158/10559965.EPI-07-2714.

9. Riaz N, Morris LG, Lee W, Chan TA. Unraveling the molecular genetics of head and neck cancer through genome-wide approaches. Genes Dis. 2014; 1(1):75-86. https://doi.org/10.1016/j.gendis.2014.07.002.

10. Vukovic V, Stojanovic J, Vecchioni A, Pastorino R, Boccia S. Systematic review and Meta-analysis of SNPs from genome-wide association studies of head and neck Cancer. Otolaryngol - Head Neck Surg (United States). 2018;159(4): 615-24. https://doi.org/10.1177/0194599818792262.

11. Deng N, Zhou H, Fan H, Yuan Y. Single nucleotide polymorphisms and cancer susceptibility. Oncotarget. 2017;8(66):110635-49. https://doi.org/10.1 8632/oncotarget.22372.

12. Kasradze D, Juodzbalys G, Guobis Z, Gervickas A, Cicciù M. Genetic and proteomic biomarkers of head-and-neck cancer: A systematic review. J Cancer Res Ther. 2020;16(3):410 Available from: http://www.cancerjournal. net/text.asp?2020/16/3/410/264692. [cited 2020 Sep 21].

13. Leoncini E, Vukovic V, Cadoni G, et al. Tumour stage and gender predict recurrence and second primary malignancies in head and neck cancer: a multicentre study within the INHANCE consortium. Eur J Epidemiol. 2018;33: 1205-18. https://doi.org/10.1007/s10654-018-0409-5. [cited 2018 Jul 31].

14. Liberati A, Altman DG, Tetzlaff J, Mulrow C, Gøtzsche PC, loannidis JP, Clarke M, Devereaux PJ, Kleijnen J, Moher D. The PRISMA statement for reporting systematic reviews and meta-analyses of studies that evaluate healthcare interventions: explanation and elaboration. BMJ. 2009;339:b2700. https://doi. org/10.1136/bmj.b2700.

15. Warren S. Multiple primary malignant tumors. A survey of the literature and a statistical study. Am J Cancer. 1932;16:1358-414 Available from: https://ci. nii.ac.jp/naid/10005037946/. [cited 2018 Jul 31].

16. GWAS - RA. GWAS Catalog [Internet]. 2015 [cited 2020 Sep 21]. p. 1-49. Available from: https://www.ebi.ac.uk/gwas/

17. NCBI. Home - dbGaP - NCBI [Internet]. Www.Ncbi.NIm.Nih.Gov. [cited 2020 Sep 21]. Available from: https://www.ncbi.nlm.nih.gov/gap/

18. GRASP. GRASP Search [Internet]. [cited 2020 Sep 21]. Available from: https:// grasp.nhlbi.nih.gov/Search.aspx

19. Sohani ZN, Meyre D, de Souza RJ, Joseph PG, Gandhi M DB. Quality of genetic association studies (Q-Genie). 2015;1-4. Available from: http://fhs. mcmaster.ca/pgp/links.html. [cited 2020 Sep 21].

20. Riley RD, Higgins JP, Deeks JJ. Interpretation of random effects metaanalyses. BMJ. 2011;342:d549. https://doi.org/10.1136/bmj.d549.

21. Dwyer T, Couper D, Walter SD. Sources of heterogeneity in the meta-analysis of observational studies: the example of SIDS and sleeping position. J Clin Epidemiol. 2001;54(5):440-7. https://doi.org/10.1016/s0895-4356(00)00313-9.

22. Egger $M$, Davey Smith G, Schneider $M$, Minder C. Bias in meta-analysis detected by a simple, graphical test. BMJ. 1997;315(7109):629-34 Available from: http://www.ncbi.nlm.nih.gov/pubmed/9310563. [cited 2018 Jul 31].

23. Li F, Sturgis EMEMEM, Chen X, Zafereo MEME, Wei Q, Li G. Association of p53 codon 72 polymorphism with risk of second primary malignancy in 
patients with squamous cell carcinoma of the head and neck. Cancer. 2010; 116(10):2350-9. https://doi.org/10.1002/cncr.25072.

24. Wang J, Lippman SMSM, Lee JJJ, Yang H, Khuri FRFR, Kim E, et al. Genetic variations in regulator of $\mathrm{G}$-protein signaling genes as susceptibility loci for second primary tumor/recurrence in head and neck squamous cell carcinoma. Carcinogenesis. 2010;31(10):1755-61. https://doi.org/10.1093/ca rcin/bgq138.

25. Lei D, Sturgis EM, Wang L-E, Liu Z, Zafereo ME, Wei Q, et al. FAS and FASLG genetic variants and risk for second primary malignancy in patients with squamous cell carcinoma of the head and neck. Cancer Epidemiol Biomark Prev. 2010;19(6):1484-91. https://doi.org/10.1158/1055-9965.EPI-10-0030.

26. Guan X, Liu Z, Liu H, Yu H, Wang LE, Sturgis EM, Li G, Wei Q. A functional variant at the miR-885-5p binding site of CASP3 confers risk of both index and second primary malignancies in patients with head and neck cancer. FASEB J. 2013;27(4):1404-12. https://doi.org/10.1096/fj.12-223420.

27. Zhang Y, Sturgis EM, Huang Z, Zafereo ME, Wei Q, Li G. Genetic variants of the p53 and p73 genes jointly increase risk of second primary malignancies in patients after index squamous cell carcinoma of the head and neck. Cancer. 2012;118(2):485-92. https://doi.org/10.1002/cncr.26222.

28. Gal TJ, Huang W-Y, Chen C, Hayes RB, Schwartz SM. DNA repair gene polymorphisms and risk of second primary neoplasms and mortality in oral cancer patients. Laryngoscope. 2005;115(12):2221-31. https://doi.org/10.1 097/01.mlg.0000183736.96004.f7.

29. Sun Y, Yu W, Sturgis EM, Peng W, Lei D, Wei Q, Song X, Li G. Site disparities in apoptotic variants as predictors of risk for second primary malignancy in patients with squamous cell carcinoma of the head and neck. BMC Cancer. 2016;16:70. https://doi.org/10.1186/s12885-016-2110-y.

30. Wang Z, Sturgis EMEM, Zhang F, Lei D, Liu Z, Xu L, et al. Genetic variants of p27 and p21 as predictors for risk of second primary malignancy in patients with index squamous cell carcinoma of head and neck. Mol Cancer. 2012s; 11(1):17. https://doi.org/10.1186/1476-4598-11-17.

31. Zhang Y, Sturgis EM, Zafereo ME, Wei Q, Li G. P14 ${ }^{\text {ARF }}$ genetic polymorphisms and susceptibility to second primary malignancy in patients with index squamous cell carcinoma of the head and neck. Cancer. 2011; 117(6):1227-35. https://doi.org/10.1002/cncr.25605.

32. Jin L, Sturgis EMEMEM, Zhang Y, Huang Z, Wei P, Guo W, et al. Genetic variants in p53-related genes confer susceptibility to second primary malignancy in patients with index squamous cell carcinoma of head and neck. Carcinogenesis. 2013;34(7):1551-7. https://doi.org/10.1093/ca rcin/bgt096.

33. Azad AK, Bairati I, Qiu X, Huang H, Cheng D, Liu G, et al. Genetic sequence variants in vitamin $D$ metabolism pathway genes, serum vitamin $D$ level and outcome in head and neck cancer patients. Int J Cancer. 2013;132(11): 2520-7. https://doi.org/10.1002/ijc.27946.

34. Minard CG, Spitz MR, Wu X, Hong WK, Etzel CJ. Evaluation of glutathione Stransferase polymorphisms and mutagen sensitivity as risk factors for the development of second primary tumors in patients previously diagnosed with early-stage head and neck cancer. Cancer. 2006;106(12):2636-44. https://doi.org/10.1002/cncr.21928.

35. Lee JJ, Wu X, Hildebrandt MAT, Yang H, Khuri FR, Kim E, et al. Global assessment of genetic variation influencing response to retinoid chemoprevention in head and neck cancer patients. Cancer Prev Res (Phila). 2011;4(2):185-93. https://doi.org/10.1158/1940-6207.CAPR-10-0125.

36. Wu X, Spitz MR, Lee JJ, Lippman SM, Ye Y, Yang H, et al. Novel susceptibility loci for second primary tumors/recurrence in head and neck cancer patients: large-scale evaluation of genetic variants. Cancer Prev Res (Phila). 2009;2(7):617-24. https://doi.org/10.1158/1940-6207.CAPR-09-0025.

37. Li F, Sturgis EM, Zafereo ME, Liu Z, Wang L-E, Wei Q, et al. p73 G4C14-toA4T14 polymorphism and risk of second primary malignancy after index squamous cell carcinoma of head and neck. Int J Cancer. 2009;125(11): 2660-5. https://doi.org/10.1002/ijc.24570.

38. Zhang X, Yang H, Lee JJ, Kim E, Lippman SM, Khuri FR, et al. MicroRNArelated genetic variations as predictors for risk of second primary tumor and/or recurrence in patients with early-stage head and neck cancer. Carcinogenesis. 2010;31(12):2118-23. https://doi.org/10.1093/carcin/bgq177.

39. Zafereo ME, Sturgis EM, Liu Z, Wang L-E, Wei Q, Li G. Nucleotide excision repair core gene polymorphisms and risk of second primary malignancy in patients with index squamous cell carcinoma of the head and neck. Carcinogenesis. 2009;30(6):997-1002. https://doi.org/10.1093/carcin/bgp096.

40. Zafereo ME, Sturgis EM, Aleem S, Chaung K, Wei Q, Li G. Glutathione Stransferase polymorphisms and risk of second primary malignancy after index squamous cell carcinoma of the head and neck. Cancer Prev Res (Phila). 2009;2(5):432-9. https://doi.org/10.1158/1940-6207.CAPR-08-0222.

41. Leoncini E, Vukovic V, Cadoni G, Pastorino R, Arzani D, Bosetti C, et al. Clinical features and prognostic factors in patients with head and neck cancer: Results from a multicentric study. Cancer Epidemiol. 2015;39(3): 367-74 Available from: http://www.ncbi.nlm.nih.gov/pubmed/25770642. [cited 2018 Jul 31].

42. Jefferies S, Kote-Jarai Z, Goldgar D, Houlston R, Frazer-Williams M-J, A'Hern R, et al. Association between polymorphisms of the GPX1 gene and second primary tumours after index squamous cell cancer of the head and neck. Oral Oncol. 2005;41(5):455-61. https://doi.org/10.1016/j.oraloncology.2004.09.012.

43. Lei D, Sturgis EM, Liu Z, Zafereo ME, Wei Q, Li G. Genetic polymorphisms of p21 and risk of second primary malignancy in patients with index squamous cell carcinoma of the head and neck. Carcinogenesis. 2010;31(2): 222-7. https://doi.org/10.1093/carcin/bgp279.

44. Khuri FR, Lee JJ, Lippman SM, Kim ES, Cooper JS, Benner SE, et al. Randomized phase III trial of low-dose isotretinoin for prevention of second primary tumors in stage I and II head and neck cancer patients. J Natl Cancer Inst. 2006;98(7):441-50 Available from: https://pubmed.ncbi.nlm.nih. gov/16595780/. [cited 2020 Sep 21].

45. Zörnig M, Hueber A, Baum W, Evan G. Apoptosis regulators and their role in tumorigenesis. Biochim Biophys Acta. 2001;1551(2):F1-37. https://doi.org/1 0.1016/s0304-419x(01)00031-2. [cited 2020 Jul 22].

46. Harris SL, Levine AJ. The p53 pathway: Positive and negative feedback loops [Internet]. Oncogene. 2005;24:2899-908 Available from: https://pubmed. ncbi.nlm.nih.gov/15838523/. [cited 2020 Jul 22].

47. Li G, Liu Z, Sturgis EM, Shi Q, Chamberlain RM, Spitz MR, Wei Q. Genetic polymorphisms of p21 are associated with risk of squamous cell carcinoma of the head and neck. Carcinogenesis. 2005;26(9):1596-602. https://doi.org/1 0.1093/carcin/bgi105.

48. Roh JW, Kim JW, Park NH, Song YS, Park IA, Park SY, et al. p53 and p21 genetic polymorphisms and susceptibility to endometrial cancer. Gynecol Oncol. 2004;93(2):499-505 Available from: https://pubmed.ncbi.nlm.nih. gov/15099969/. [cited 2020 Jul 22].

49. Keshava C, Frye BL, Wolff MS, McCanlies EC, Weston A. Waf-1 (p21) and p53 polymorphisms in breast cancer. Cancer Epidemiol Biomarkers Prev. 2002; 11(1):127-30. Erratum in: Cancer Epidemiol Biomarkers Prev. 2004 Oct;13(10): 1682. PMID: 11815410.

50. Choi YY, Kang HK, Choi JE, Jang JS, Kim EJ, Cha Sl, et al. Comprehensive assessment of P21 polymorphisms and lung cancer risk. J Hum Genet. 2008;53(1): 87-95 Available from: http://www.ncbi.nlm.nih.gov/SNP. [cited 2020 Jul 22].

51. Chen J, Killary AM, Sen S, Amos Cl, Evans DB, Abbruzzese JL, et al. Polymorphisms of p21 and p27 jointly contribute to an earlier age at diagnosis of pancreatic cancer. Cancer Lett. 2008;272(1):32-9. Available from: https://pubmed.ncbi.nlm.nih.gov/18694622/. [cited 2020 Jul 22].

52. Zhang Z, Wang LE, Sturgis EM, El-Naggar AK, Hong WK, Amos Cl, et al. Polymorphisms of FAS and FAS ligand genes involved in the death pathway and risk and progression of squamous cell carcinoma of the head and neck. Clin Cancer Res. 2006;12(18):5596-602 Available from: https:// pubmed.ncbi.n/m.nih.gov/17000697/. [cited 2020 Jul 22].

53. Ueda M, Terai $Y$, Kanda K, Kanemura M, Takehara M, Yamaguchi $H$, et al. Fas gene promoter -670 polymorphism in gynecological cancer. Int J Gynecol Cancer. 2006;16(S1):179-82 Available from: https://ijgc.bmj.com/lookup/ doi/10.1111/j.1525-1438.2006.00505.x. [cited 2020 Jul 22].

54. Sun T, Miao X, Zhang X, Tan W, Xiong P, Lin D. Polymorphisms of death pathway genes FAS and FASL in esophageal squamous-cell carcinoma. J Natl Cancer Inst. 2004;96(13):1030-6. https://doi.org/10.1093/jnci/djh187.

55. Crew KD, Gammon MD, Terry MB, Zhang FF, Agrawal M, Eng SM, et al. Genetic polymorphisms in the apoptosis-associated genes FAS and FASL and breast cancer risk. Carcinogenesis. 2007;28(12):2548-51. https://doi.org/1 0.1093/carcin/bgm211.

56. Hashibe M, Brennan P, Strange RC, Bhisey R, Cascorbi I, Lazarus P, et al. Meta- and pooled analyses of GSTM1, GSTT1, GSTP1, and CYP1A1 genotypes and risk of head and neck cancer. Cancer Epidemiol Biomarkers Prev. 2003;12(12):1509-17 Available from: http://www.ncbi.nlm.nih.gov/ pubmed/14693745. [cited 2020 Jul 22].

57. Stücker I, Hirvonen A, de Waziers I, Cabelguenne A, Mitrunen K, Cénée S, et al. Genetic polymorphisms of glutathione S-transferases as modulators of lung cancer susceptibility - PubMed [Internet]. Carcinogenesis. 2002;23(9): 1475-81. Available from: https://pubmed.ncbi.nlm.nih.gov/12189190/. [cited 2020 Jul 22]. 
58. Park SK, Yim DS, Yoon KS, Choi IM, Choi JY, Yoo KY, et al. Combined effect of GSTM1, GSTT1, and COMT genotypes in individual breast cancer risk. Breast Cancer Res Treat. 2004;88(1):55-62. Available from: https://pubmed. ncbi.nlm.nih.gov/15538046/. [cited 2020 Jul 22].

\section{Publisher's Note}

Springer Nature remains neutral with regard to jurisdictional claims in published maps and institutional affiliations.

Ready to submit your research? Choose BMC and benefit from:

- fast, convenient online submission

- thorough peer review by experienced researchers in your field

- rapid publication on acceptance

- support for research data, including large and complex data types

- gold Open Access which fosters wider collaboration and increased citations

- maximum visibility for your research: over $100 \mathrm{M}$ website views per year

At $\mathrm{BMC}$, research is always in progress.

Learn more biomedcentral.com/submissions 